Documentation of the Caddo Ceramic Vessels from the Culpepper Site (41HP1) in Hopkins County in the Upper Sulphur River Basin in East Texas

Timothy K. Perttula

Heritage Research Center, Stephen F. Austin State University

Follow this and additional works at: https://scholarworks.sfasu.edu/ita

Part of the American Material Culture Commons, Archaeological Anthropology Commons, Environmental Studies Commons, Other American Studies Commons, Other Arts and Humanities Commons, Other History of Art, Architecture, and Archaeology Commons, and the United States History Commons

Tell us how this article helped you.

This Article is brought to you for free and open access by the Center for Regional Heritage Research at SFA ScholarWorks. It has been accepted for inclusion in Index of Texas Archaeology: Open Access Gray Literature from the Lone Star State by an authorized editor of SFA ScholarWorks. For more information, please contact cdsscholarworks@sfasu.edu. 
Documentation of the Caddo Ceramic Vessels from the Culpepper Site (41HP1) in Hopkins County in the Upper Sulphur River Basin in East Texas

\section{Creative Commons License}

\section{(c) (1) \&}

This work is licensed under a Creative Commons Attribution-NonCommercial 4.0 International License 


\title{
Documentation of the Caddo Ceramic Vessels from the Culpepper Site (41HP1) in Hopkins County in the Upper Sulphur River Basin in East Texas
}

\author{
Timothy K. Perttula
}

\section{Introduction}

The Culpepper site (41HP1) is a late (post-A.D. 1600) Titus phase site in the upper Sulphur River basin in East Texas (Figure 1). It is on a sandy knoll alongside Stouts Creek, a small northward-flowing stream in the White Oak Creek basin of the larger Sulphur River drainage. The site is in the modern-day Post Oak Savannah (Diggs et al. 2006:Figure 2), but there are areas of tall grass prairie between Stouts Creek and White Oak Creek; the larger White Oak and Sulphur prairies lie approximately $15 \mathrm{~km}$ to the west and northwest (see Jordan 1981).

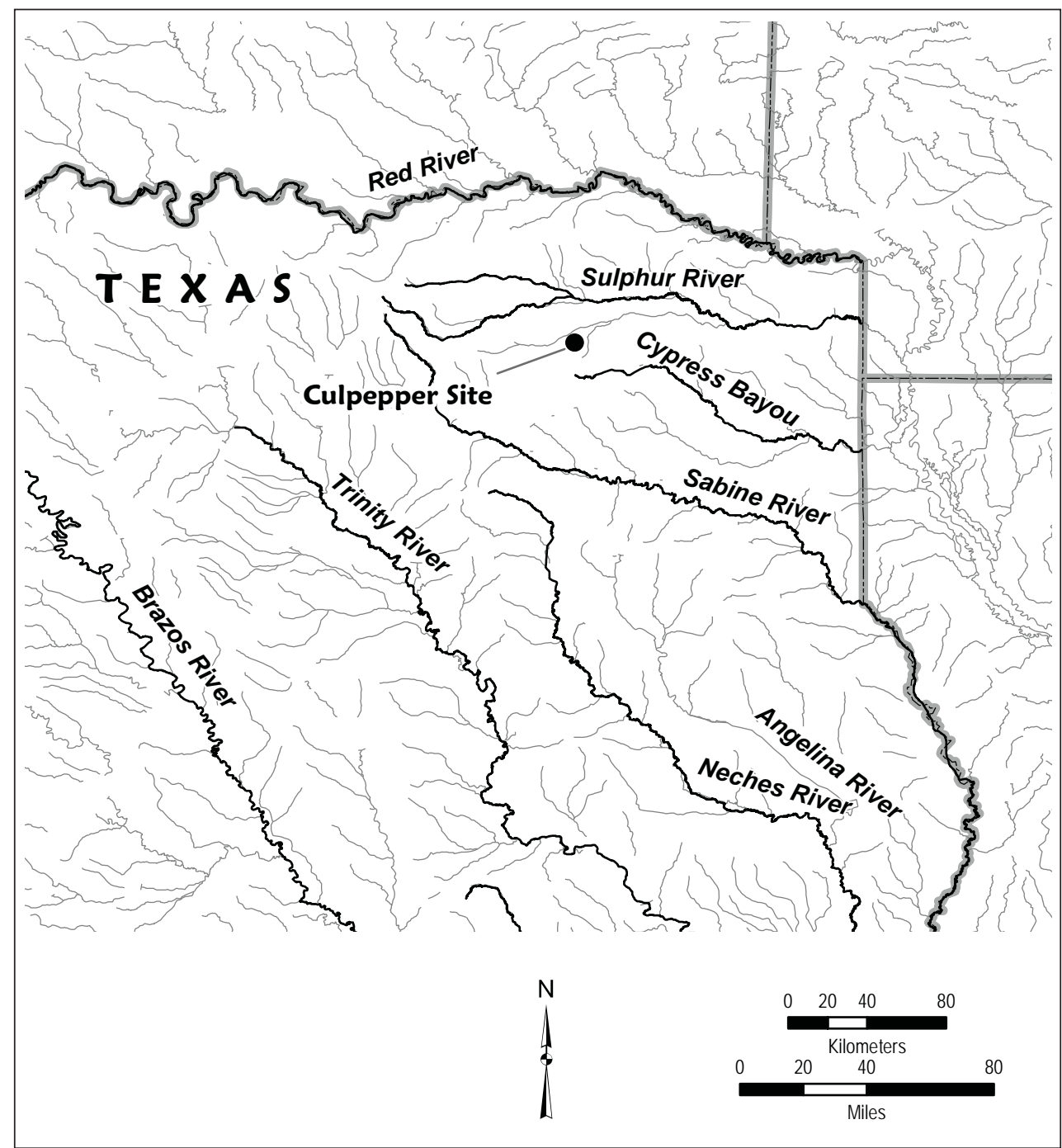

Figure 1. The location of the Culpepper site (41HP1) in East Texas. 
Excavations at the Culpepper site by University of Texas (UT) archaeologists in 1931 uncovered a number of ancestral Caddo burial features with associated ceramic vessel funerary offerings. These ceramic vessels are presently curated at the Texas Archeological Research Laboratory at The University of Texas at Austin (TARL). In this article I document and analyze the Culpepper site vessels to better ascertain the likely chronological age and social and cultural affiliation of the Caddo populations that occupied the Stouts Creek area, as well as their interrelationships with other known Caddo communities in East Texas.

\section{Archaeological Context}

The Culpepper site is one of a number of known late Titus phase Caddo sites along Stouts Creek in Hopkins County, Texas (Figure 2). These sites have habitation archaeological deposits as well as family cemeteries. They are part of a very distinctive western Titus phase community that lived in the Post Oak Savannah in the Stouts Creek valley in the $16^{\text {th }}$ century and much of the $17^{\text {th }}$ century A.D (see Perttula 2009). Their unique archaeological nature rests in the character of their material culture: particularly with the fine ware and utility ware ceramics they made and used (among them Anglin Impressed, a new utility ware type), as well as the abundance of clay ear spools and figurine fragments found in domestic contexts, suggesting they were in regular use within the community, and the use of marine shell Clements style ear disks, also found in domestic contexts. These particular kinds of artifacts are rarely found at any other Caddo sites in Northeast Texas, and thus they speak to the distinctive cultural practices and adaptive strategies employed by this Titus phase community to successfully thrive in the Post Oak Savannah of Northeast Texas. By all measures, this community thrived until ca. A.D. 1700, after which the Caddo apparently abandoned the area.

The Culpepper site was excavated in May 1931 by a UT archaeological crew led by A. T. Jackson (Scurlock 1962:286). The work focused on a small cemetery on a sandy knoll on the east side of Stouts Creek (Figure 3 ). There was a midden deposit about $25 \mathrm{~m}$ southwest of the cemetery, and ceramic sherds and projectile points were recovered in the UT work there (Scurlock 1962:301-310).

In the early 1900s, a flood along Stouts Creek exposed human skeletons and associated ceramic vessels; in following years collectors periodically worked out at the site, and according to Scurlock (1962:286), these collectors dug 14 burials and recovered 25 pottery vessels. The site came to the attention of UT in September 1930, when they purchased a number of vessels from the site that had been in the collections of a B. F. Perkins of Weaver, Texas. UT followed up the ceramic vessel purchases by conducting field work the following year (see Figure 3).

The 1931 UT excavations uncovered eight burial features (Table 1) in all parts of the sandy knoll (see Figure 3). These were single, extended supine Caddo burials, mainly placed in the grave pits with their heads facing west, southwest, or northwest. Burials 2, 3, and 7 had been previously disturbed by collectors, Burial 1 had been disturbed by flooding along Stouts Creek, and Burials 4 and 8 had been disturbed by plowing and or past flooding (Scurlock 1962:288). Associated funerary offerings included whole or portions of 39 ceramic vessels, three Talco arrow points (Scurlock 1962:Figure 12g), and one celt (Scurlock 1962:Figure 14c). 


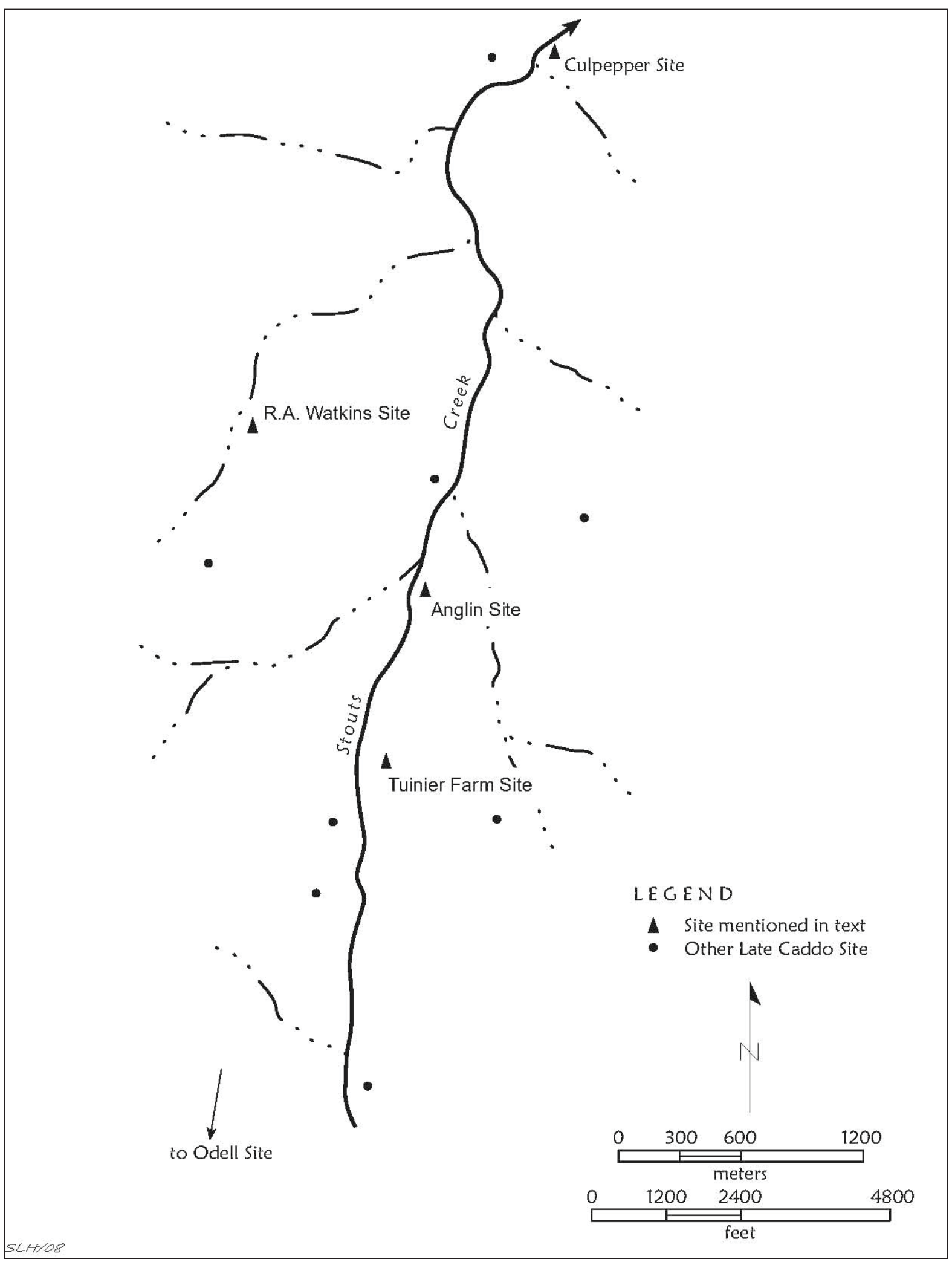

Figure 2. Sixteenth and seventeenth century Caddo sites on Stouts Creek in Hopkins County, Texas. 


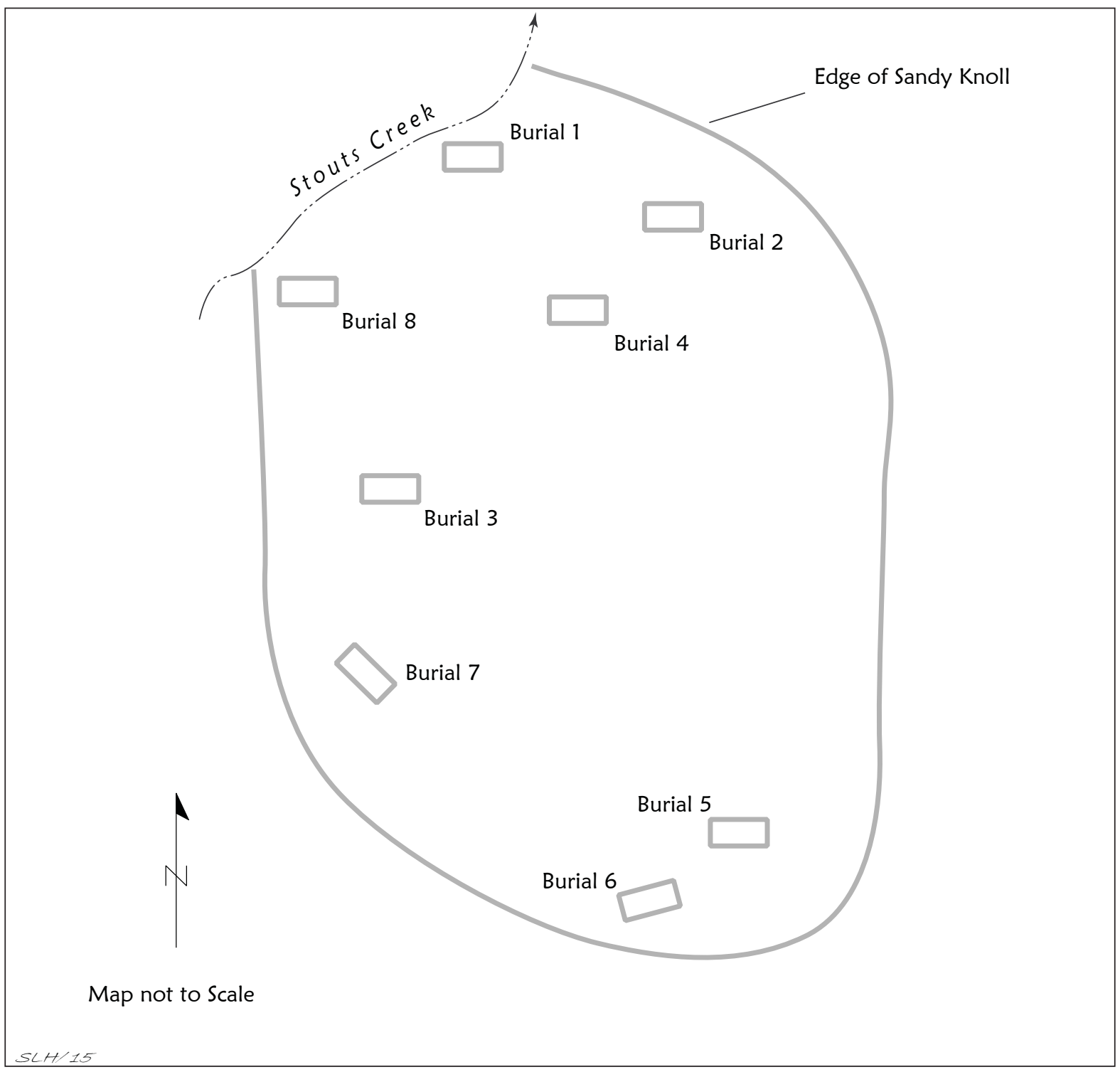

Figure 3. Excavated burial features at the Culpepper site (after Scurlock 1962:Figure 2).

Table 1. Burial features at the Culpepper site.

\begin{tabular}{llll}
\hline Burial No. & Orientation & Vessels & Other funerary offerings \\
\hline 1 & facing west & 5 & 1 celt \\
2 & facing west & 6 & - \\
3 & Unknown & 4 & - \\
4 & Unknown & 3 & 3 Talco arrow points \\
5 & facing west & 5 & - \\
6 & facing southwest & 7 & - \\
7 & facing northwest & 5 & clay pigment inside one of the vessels \\
8 & facing west & 4 & - \\
\hline
\end{tabular}




\section{Vessel Documentation}

At the present time, only 36 vessels from the Culpepper site could be located in the TARL collections; one of these vessels is presently on loan to the Star of the Republic Museum in Washington on the Brazos, Texas. In addition to eight vessels from the site purchased by UT in 1930, and one vessel with no known provenience, there are 27 ceramic vessels from Burials 1, 2, 3, 5, 6, and 7 in the TARL collections. None of the vessels from Burials 4 and 8 were located in the TARL collections. According to Scurlock (1962:290291), the vessels from Burial 4 included Taylor Engraved, Hodges Engraved, and Nash Neck Banded, while those from Burial 8 were identified as Taylor Engraved, Ripley Engraved (n=2), and one of unknown type that was missing from the collection when Scurlock analyzed the Culpepper site vessels.

SITE NAME OR SITE NUMBER: Culpepper

VESSEL NO.: 1X, B. F. Perkins collection, purchased September 1930

VESSEL FORM: Bottle with a spool neck

NON-PLASTICS AND PASTE: grog

RIM AND LIP FORM: Everted to direct rim and rounded lip

CORE COLOR: B (fired and cooled in a reducing environment)

INTERIOR SURFACE COLOR: very dark grayish-brown

EXTERIOR SURFACE COLOR:

very dark grayish-brown

WALL THICKNESS (IN MM): rim, $5.7 \mathrm{~mm}$

INTERIOR SURFACE TREATMENT: none

EXTERIOR SURFACE TREATMENT:

smoothed

HEIGHT (IN CM): 12.7

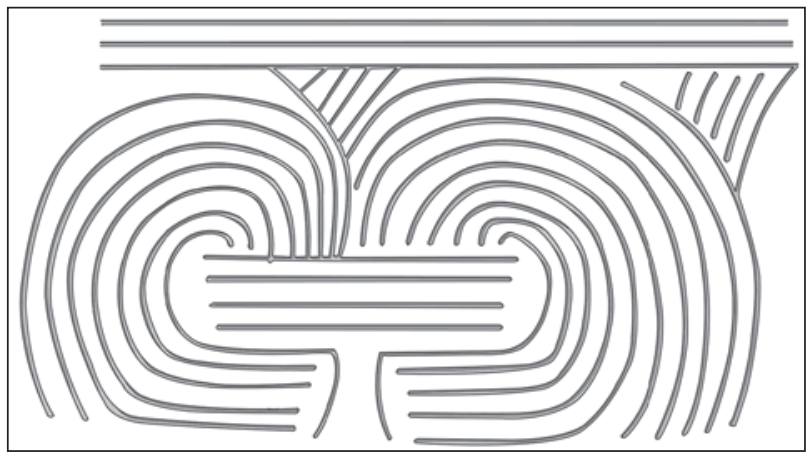

Figure 4. Decorative elements on a Keno Trailed bottle (Vessel 1X) from the Culpepper site.

ORIFICE DIAMETER (IN CM): 4.4

DIAMETER AT BOTTOM OF RIM OR NECK (IN CM): 4.6; maximum body diameter is $12.1 \mathrm{~cm}$

BASE DIAMETER (IN CM) AND SHAPE OF BASE: 7.2; circular and flat

ESTIMATED VOLUME (IN LITERS): 0.37

DECORATION (INCLUDING MOTIF AND ELEMENTS WHEN APPARENT): The top of the vessel body has three horizontal trailed lines. The remainder of the vessel has two sets of opposed semi-circular trailed lines on either side of four centrally located short horizontal trailed lines (Figure 4). At the upper end of the vessel body, dividing the opposed semi-circular trailed lines, are four sets of hatched triangular elements.

PIGMENT USE AND LOCATION ON VESSEL: none

TYPE AND VARIETY (IF KNOWN): Keno Trailed 
SITE NAME OR SITE NUMBER: Culpepper

VESSEL NO.: 2X, B. F. Perkins collection, purchased September 1930

VESSEL FORM: Bottle with a spool neck

NON-PLASTICS AND PASTE: grog

RIM AND LIP FORM: Everted to direct rim and exterior folded lip

CORE COLOR: B (fired and cooled in a reducing environment)

INTERIOR SURFACE COLOR: very dark grayish-brown

EXTERIOR SURFACE COLOR: very dark

grayish-brown; fire clouds on the body

WALL THICKNESS (IN MM):

rim, $4.9 \mathrm{~mm}$

INTERIOR SURFACE

TREATMENT: none

EXTERIOR SURFACE

TREATMENT: smoothed

HEIGHT (IN CM): 16.0

ORIFICE DIAMETER (IN CM): 4.8

DIAMETER AT BOTTOM OF RIM

OR NECK (IN CM): 4.6; maximum

body diameter is $12.3 \mathrm{~cm}$

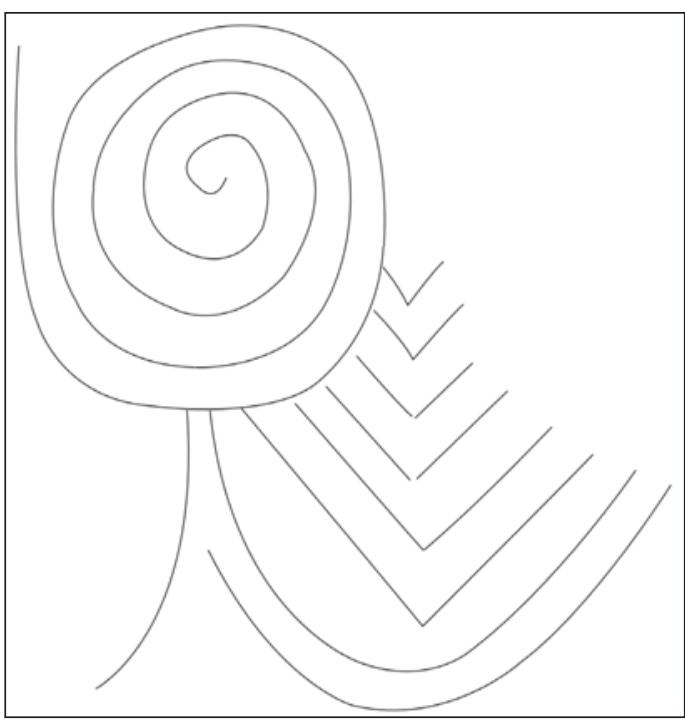

Figure 5. Decorative elements on a Taylor Engraved bottle (Vessel 2X) from the Culpepper site.

BASE DIAMETER (IN CM) AND

SHAPE OF BASE: 5.1 ; circular and flat

ESTIMATED VOLUME (IN LITERS): 0.33

DECORATION (INCLUDING MOTIF AND ELEMENTS WHEN APPARENT): The upper part of the vessel body has four sets of engraved spiral elements that end in a curled arm (Figure 5). The lower part of the vessel body has four sets of engraved diagonal opposed lines and curvilinear lines that connect the engraved spiral elements together.

PIGMENT USE AND LOCATION ON VESSEL: none

TYPE AND VARIETY (IF KNOWN): Taylor Engraved 
SITE NAME OR SITE NUMBER: Culpepper

VESSEL NO.: 3X, B. F. Perkins collection, purchased September 1930

VESSEL FORM: Bottle

NON-PLASTICS AND PASTE: grog

RIM AND LIP FORM: Inverted rim and rounded, exterior folded lip

CORE COLOR: B (fired and cooled in a reducing environment)

INTERIOR SURFACE COLOR: very dark grayish-brown

EXTERIOR SURFACE COLOR:

very dark grayish-brown

WALL THICKNESS (IN MM):

rim, $7.2 \mathrm{~mm}$

INTERIOR SURFACE

TREATMENT: none

EXTERIOR SURFACE

TREATMENT: smoothed

HEIGHT (IN CM): 18.8

ORIFICE DIAMETER (IN CM): 3.8

DIAMETER AT BOTTOM OF RIM OR

NECK (IN CM): 5.1; maximum body

diameter is $13.3 \mathrm{~cm}$

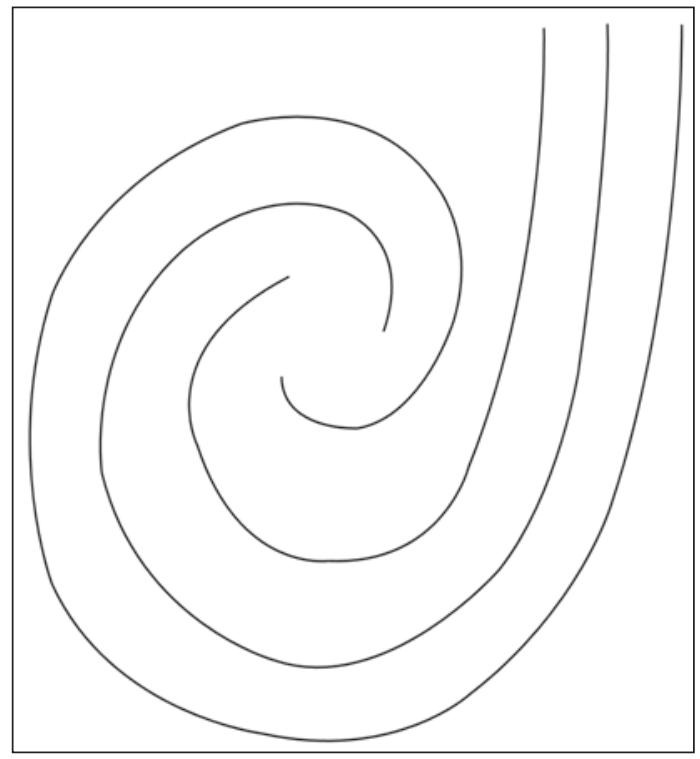

BASE DIAMETER (IN CM) AND SHAPE

OF BASE: 5.1; circular and rounded

Figure 6. Decorative elements on a Keno Trailed bottle (3X) from the Culpepper site.

ESTIMATED VOLUME (IN LITERS): 0.38

DECORATION (INCLUDING MOTIF AND ELEMENTS WHEN APPARENT): The vessel body has four upper and four lower sets of three trailed spirals that end in a hooked arm element (Figure 6).

PIGMENT USE AND LOCATION ON VESSEL: white clay pigment in engraved lines

TYPE AND VARIETY (IF KNOWN): Keno Trailed 
SITE NAME OR SITE NUMBER: Culpepper

VESSEL NO.: 6X, B. F. Perkins Collection, purchased September 1930. Currently (June 2015), the vessel is on long term loan to the Star of the Republic Museum in Washington on the Brazos, Texas, and was not available for documentation.

SITE NAME OR SITE NUMBER: Culpepper

VESSEL NO.: 7X, B. F. Perkins Collection, purchased September 1930

VESSEL FORM: Carinated bowl

NON-PLASTICS AND PASTE: grog

RIM AND LIP FORM: Inverted rim and rounded lip

CORE COLOR: F (fired in a reducing environment and cooled in the open air)

INTERIOR SURFACE COLOR: yellowish-brown

EXTERIOR SURFACE COLOR: yellowish-brown; fire clouds on the rim, body, and base

WALL THICKNESS (IN MM): rim, $6.9 \mathrm{~mm}$

INTERIOR SURFACE TREATMENT: burnished on the rim and smoothed on the body

EXTERIOR SURFACE

TREATMENT: burnished

HEIGHT (IN CM): 15.8

ORIFICE DIAMETER

(IN CM): 22.9

DIAMETER AT BOTTOM

OF RIM OR NECK

(IN CM): 23.3

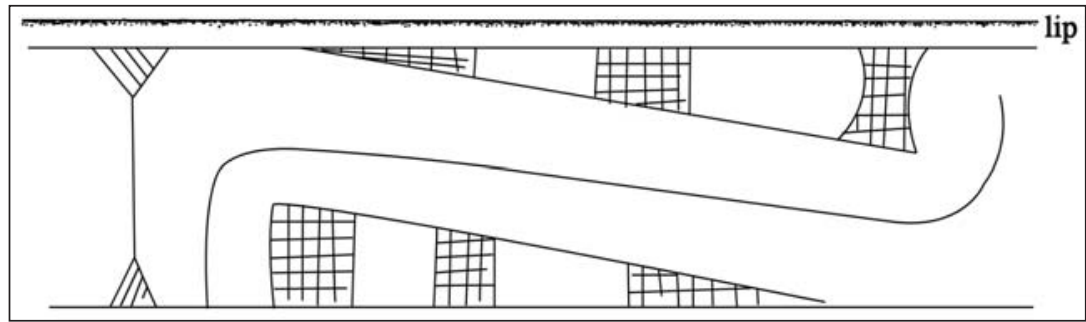

Figure 7. Decorative elements on Ripley Engraved, var. Gandy carinated bowl (7X) from the Culpepper site.

BASE DIAMETER (IN CM) AND SHAPE OF BASE: 8.9; circular and flat

ESTIMATED VOLUME (IN LITERS): 3.3

DECORATION(INCLUDINGMOTIFANDELEMENTS WHENAPPARENT): The rim has four repeating sets of straight to slanting engraved scrolls divided by single vertical engraved lines with upper and lower hatched pendant triangles (Figure 7). The upper and lower scroll fill zones have cross-hatched columns, brackets, and triangle elements. These column elements are similar to those on Ripley Engraved, var. Gandy-Mockingbird defined by Fields et al. (2014:Table 8.6), except that there are no cross-hatched elements between the scrolls.

PIGMENT USE AND LOCATION ON VESSEL: none

TYPE AND VARIETY (IF KNOWN): Ripley Engraved, var. Gandy 
SITE NAME OR SITE NUMBER: Culpepper

VESSEL NO.: 8X, B. F. Perkins Collection, purchased in September 1930

VESSEL FORM: Carinated bowl

NON-PLASTICS AND PASTE: grog

RIM AND LIP FORM: Inverted rim and rounded, exterior folded lip

CORE COLOR: F (fired in a reducing environment and cooled in the open air)

INTERIOR SURFACE COLOR: brown; fire clouds on the body and base

EXTERIOR SURFACE COLOR: brown; fire clouds on the body and base

WALL THICKNESS (IN MM): rim, $6.5 \mathrm{~mm}$

INTERIOR SURFACE TREATMENT: smoothed

EXTERIOR SURFACE TREATMENT: burnished

HEIGHT (IN CM): 15.8

ORIFICE DIAMETER (IN CM): 22.5

DIAMETER AT BOTTOM OF RIM OR NECK (IN CM): 23.1

BASE DIAMETER (IN CM) AND SHAPE OF BASE: 8.0; circular and flat

ESTIMATED VOLUME (IN LITERS): 3.2

DECORATION (INCLUDING MOTIF AND ELEMENTS WHEN APPARENT): The rim panel has four repeating sets of engraved slanting scrolls divided by engraved brackets (Figure 8 ). The engraved brackets have two short linear tick marks. The upper and lower scroll fill zones have excised brackets and triangle elements divided by single vertical engraved lines (Figure 8).

PIGMENT USE AND LOCATION ON VESSEL: none

TYPE AND VARIETY (IF KNOWN): Ripley Engraved, var. Gandy

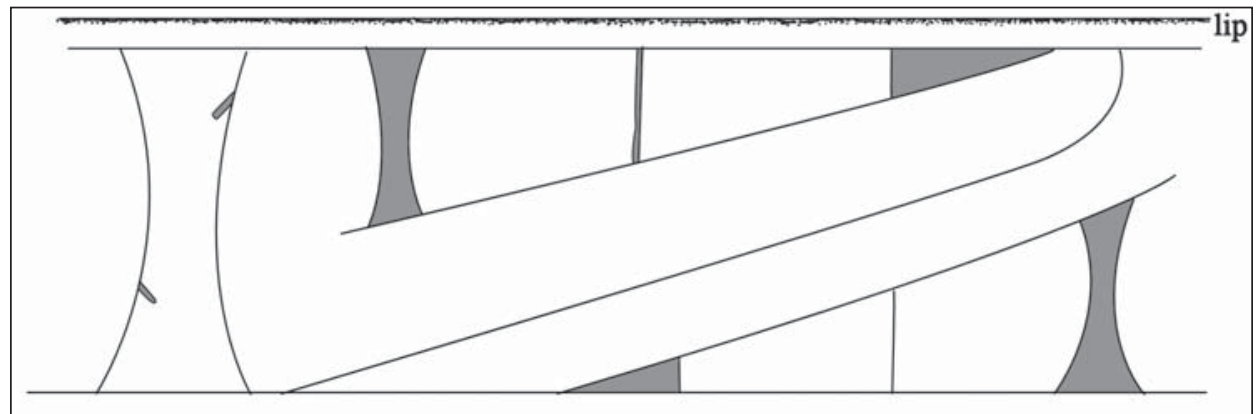

Figure 8. Decorative elements on a Ripley Engraved, var. Gandy (8X) carinated bowl from the Culpepper site. 
SITE NAME OR SITE NUMBER: Culpepper

VESSEL NO.: 9X, B. F. Perkins Collection, purchased in September 1930

VESSEL FORM: Carinated bowl

NON-PLASTICS AND PASTE: grog

RIM AND LIP FORM: Inverted rim and rounded lip

CORE COLOR: F (fired in a reducing environment and cooled in the open air)

INTERIOR SURFACE COLOR: light yellowish-brown

EXTERIOR SURFACE COLOR: light yellowish-brown; fire clouds on the rim, body, and base

WALL THICKNESS (IN MM): rim, $5.6 \mathrm{~mm}$

INTERIOR SURFACE TREATMENT: smoothed on the rim

EXTERIOR SURFACE TREATMENT: smoothed

HEIGHT (IN CM): 10.0

ORIFICE DIAMETER (IN CM): 15.2

DIAMETER AT BOTTOM OF RIM OR NECK (IN CM): 16.7

BASE DIAMETER (IN CM) AND SHAPE OF BASE: 6.4; circular and flat

ESTIMATED VOLUME (IN LITERS): 0.9

DECORATION (INCLUDING MOTIF AND ELEMENTS WHEN APPARENT): The rim panel has four sets of slanting engraved scrolls divided by open brackets (Figure 9). The upper scroll fill zone is plain, but the lower scroll fill zones have two or three sets of two stacked triangle elements filled with vertical or diagonal hatched engraved lines.

PIGMENT USE AND LOCATION ON VESSEL: none

TYPE AND VARIETY (IF KNOWN): Ripley Engraved, var. Gandy

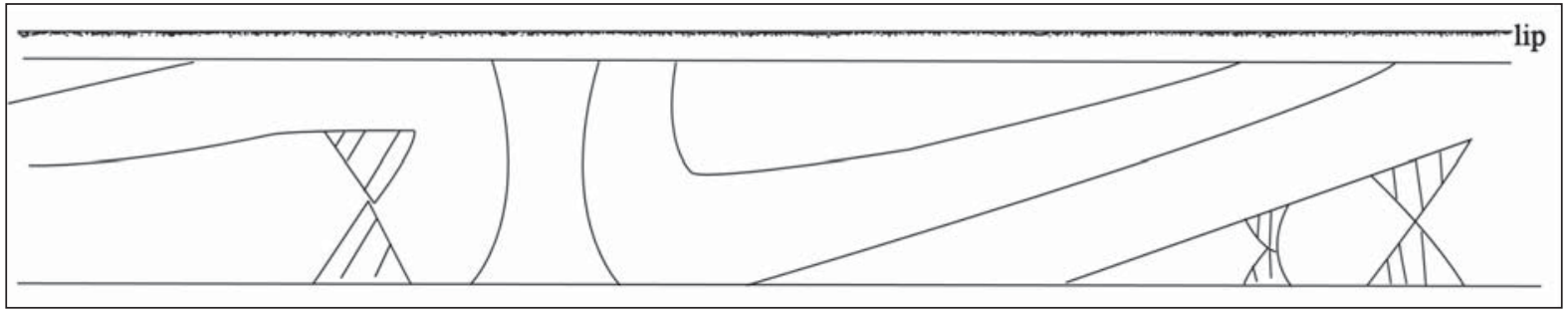

Figure 9. Decorative elements on a Ripley Engraved, var. Gandy carinated bowl (9X) from the Culpepper site. 
SITE NAME OR SITE NUMBER: Culpepper

VESSEL NO.: 18X, B. F. Perkins Collection, purchased in September 1930

VESSEL FORM: Carinated bowl

NON-PLASTICS AND PASTE: grog

RIM AND LIP FORM: Direct rim and rounded, exterior folded lip

CORE COLOR: F (fired in a reducing environment and cooled in the open air)

INTERIOR SURFACE COLOR: red; fire clouds on the rim

EXTERIOR SURFACE COLOR: red; fire clouds on the rim and body

WALL THICKNESS (IN MM): rim, $7.4 \mathrm{~mm}$

INTERIOR SURFACE TREATMENT: smoothed

EXTERIOR SURFACE TREATMENT: burnished

HEIGHT (IN CM): 15.4

ORIFICE DIAMETER (IN CM): 25.0

DIAMETER AT BOTTOM OF RIM OR NECK (IN CM): 24.8

BASE DIAMETER (IN CM) AND SHAPE OF BASE: 7.8; circular and flat

ESTIMATED VOLUME (IN LITERS): 3.5

DECORATION (INCLUDING MOTIF AND ELEMENTS WHEN APPARENT): The vessel has a red slip on interior and exterior surfaces. The rim panel has four repeated sets of engraved slanting scroll elements divided by excised brackets (Figure 10); the upper and lower ends of the slanting scrolls end in small excised triangle elements. The upper and lower scroll fill zones have excised brackets, vertical columns, and triangle elements.

PIGMENT USE AND LOCATION ON VESSEL: none

TYPE AND VARIETY (IF KNOWN): Ripley Engraved, var. Gandy

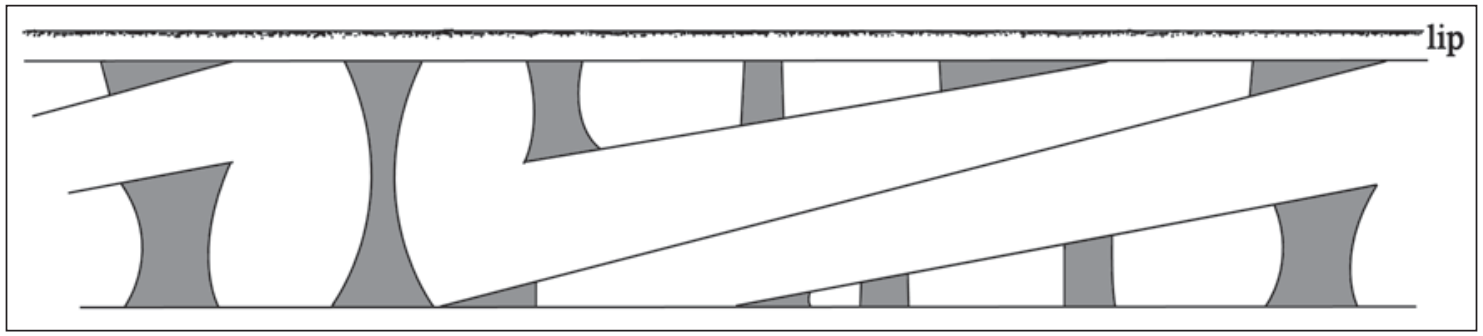

Figure 10. Decorative elements on a Ripley Engraved, var. Gandy carinated bowl (18X) from the Culpepper site. 
SITE NAME OR SITE NUMBER: Culpepper

VESSEL NO.: 1, Burial 1

VESSEL FORM: Carinated bowl

NON-PLASTICS AND PASTE: grog

RIM AND LIP FORM: Inverted rim and rounded lip; lip notched

CORE COLOR: B (fired and cooled in a reducing environment)

INTERIOR SURFACE COLOR: very dark grayish-brown

EXTERIOR SURFACE COLOR: very dark grayish-brown

WALL THICKNESS (IN MM): rim, 5.6 mm

INTERIOR SURFACE TREATMENT: smoothed

EXTERIOR SURFACE TREATMENT: smoothed

HEIGHT (IN CM): 10.2

ORIFICE DIAMETER (IN CM): 13.8

DIAMETER AT BOTTOM OF RIM OR NECK (IN CM): 14.2

BASE DIAMETER (IN CM) AND SHAPE OF BASE: 3.7; circular and rounded

ESTIMATED VOLUME (IN LITERS): 0.8

DECORATION (INCLUDING MOTIF AND ELEMENTS WHEN APPARENT): The rim panel has a single horizontal engraved line below the vessel lip. The panel is divided into four sections by sets of three closely-spaced vertical engraved lines. The horizontal engraved line has a continuous series of small excised triangular tick marks, except in the area between the vertical engraved lines (Figure 11).

PIGMENT USE AND LOCATION ON VESSEL: none

TYPE AND VARIETY (IF KNOWN): Simms Engraved

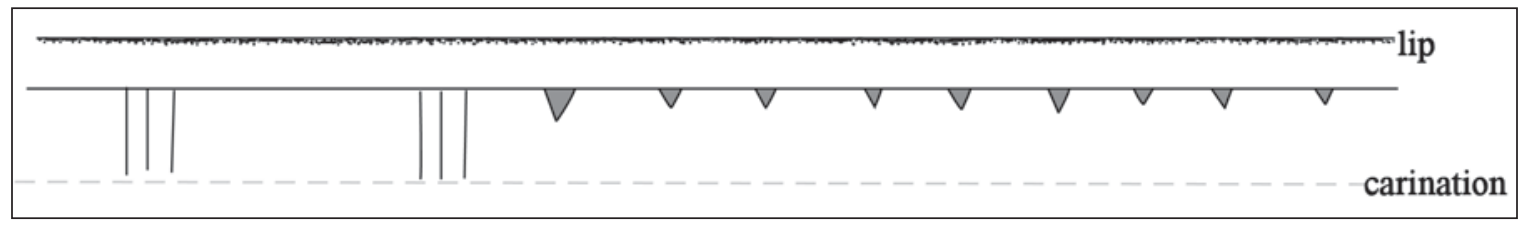

Figure 11. Simms Engraved carinated bowl (No. 1) in Burial 1 at the Culpepper site. 
SITE NAME OR SITE NUMBER: Culpepper

VESSEL NO.: 2, Burial 1

VESSEL FORM: Carinated bowl

NON-PLASTICS AND PASTE: grog

RIM AND LIP FORM: Inverted rim and rounded lip

CORE COLOR: F (fired in a reducing environment and cooled in the open air)

INTERIOR SURFACE COLOR: red

EXTERIOR SURFACE COLOR: red; fire clouds on the body and base

WALL THICKNESS (IN MM): rim, $6.3 \mathrm{~mm}$

INTERIOR SURFACE TREATMENT: burnished

EXTERIOR SURFACE TREATMENT: burnished

HEIGHT (IN CM): 7.8

ORIFICE DIAMETER (IN CM): 14.0

DIAMETER AT BOTTOM OF RIM OR NECK (IN CM): 14.2

BASE DIAMETER (IN CM) AND SHAPE OF BASE: 6.4; circular and flat

ESTIMATED VOLUME (IN LITERS): 0.7

DECORATION (INCLUDING MOTIF AND ELEMENTS WHEN APPARENT): The interior and exterior surfaces of the vessel have a red slip. The rim panel is divided into four sections by sets of four vertical or vertical-curvilinear engraved lines. The panels have either three or four large upper and lower excised triangles (Figure 12).

PIGMENT USE AND LOCATION ON VESSEL: none

TYPE AND VARIETY (IF KNOWN): Unidentified fine ware

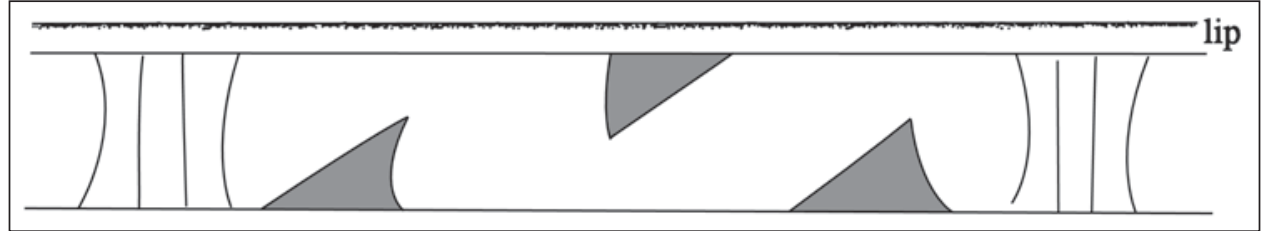

Figure 12. Decorative elements on engraved carinated bowl (No. 2) in Burial 1 at the Culpepper site. 
SITE NAME OR SITE NUMBER: Culpepper

VESSEL NO.: 3, Burial 1

VESSEL FORM: Carinated bowl

NON-PLASTICS AND PASTE: grog

RIM AND LIP FORM: Inverted rim and rounded lip

CORE COLOR: F (fired in a reducing environment and cooled in the open air)

INTERIOR SURFACE COLOR: red; fire clouds on the body and base; organic residue on the rim

EXTERIOR SURFACE COLOR: red; fire clouds on the rim; organic residue on the rim and body

WALL THICKNESS (IN MM): rim, $6.9 \mathrm{~mm}$; body, $7.4 \mathrm{~mm}$

INTERIOR SURFACE TREATMENT: smoothed

EXTERIOR SURFACE TREATMENT: burnished

HEIGHT (IN CM): 13.0

ORIFICE DIAMETER (IN CM): 21.0

DIAMETER AT BOTTOM OF RIM OR NECK (IN CM): 21.2

BASE DIAMETER (IN CM) AND SHAPE OF BASE: 10.2; circular and flat

ESTIMATED VOLUME (IN LITERS): 2.5

DECORATION (INCLUDING MOTIF AND ELEMENTS WHEN APPARENT): The interior and exterior vessel surfaces have a red slip. The rim panel has four engraved slanting scroll elements with no primary element between the scroll lines; the slanting scroll lines have excised triangle elements at their upper and lower ends. The upper and lower scroll fill zones have excised brackets and triangle elements (Figure 13).

PIGMENT USE AND LOCATION ON VESSEL: white clay pigment in the engraved lines

TYPE AND VARIETY (IF KNOWN): Ripley Engraved, var. Carpenter

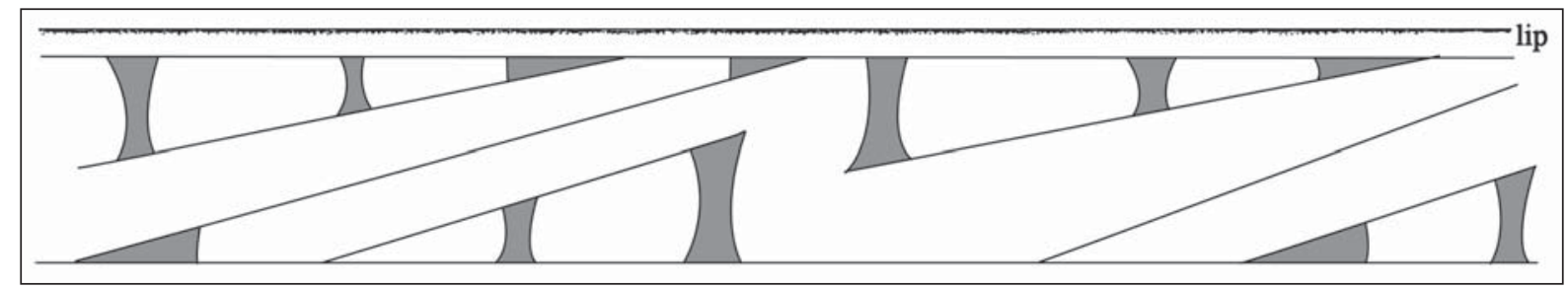

Figure 13. Decorative elements on Ripley Engraved, var. Carpenter carinated bowl (No. 3) in Burial 1 at the Culpepper site. 
SITE NAME OR SITE NUMBER: Culpepper

VESSEL NO.: 4, Burial 1

VESSEL FORM: Jar

NON-PLASTICS AND PASTE: grog

RIM AND LIP FORM: Everted rim and rounded lip

CORE COLOR: $\mathrm{G}$ (fired in a reducing environment and cooled in the open air)

INTERIOR SURFACE COLOR: dark grayish-brown; extensive organic residue on the rim and body

EXTERIOR SURFACE COLOR: yellowish-brown; fire clouds on the rim and body

WALL THICKNESS (IN MM): rim, $7.6 \mathrm{~mm}$

INTERIOR SURFACE TREATMENT: smoothed

EXTERIOR SURFACE TREATMENT: smoothed on the body

HEIGHT (IN CM): 27.9

ORIFICE DIAMETER (IN CM): 23.4

DIAMETER AT BOTTOM OF RIM OR NECK (IN CM): 21.7

BASE DIAMETER (IN CM) AND SHAPE OF BASE: 8.9; circular and flat

ESTIMATED VOLUME (IN LITERS): 8.5

DECORATION (INCLUDING MOTIF AND ELEMENTS WHEN APPARENT): The rim has five rows of horizontal neck bands as well as four sets of two short vertical appliqued ridges. The vessel body has four vertical appliqued ridges that extend from the rim-body juncture to within $10 \mathrm{~cm}$ of the vessel base.

PIGMENT USE AND LOCATION ON VESSEL: none

TYPE AND VARIETY (IF KNOWN): La Rue Neck Banded 
SITE NAME OR SITE NUMBER: Culpepper

VESSEL NO.: 6, Burial 1

VESSEL FORM: Carinated bowl

NON-PLASTICS AND PASTE: grog

RIM AND LIP FORM: Inverted rim and rounded lip

CORE COLOR: F (fired in a reducing environment and cooled in the open air)

INTERIOR SURFACE COLOR: yellowish-brown

EXTERIOR SURFACE COLOR: yellowish-brown; fire clouds on the rim, body, and base

WALL THICKNESS (IN MM): rim, $5.2 \mathrm{~mm}$; body, $6.7 \mathrm{~mm}$

INTERIOR SURFACE TREATMENT: smoothed

EXTERIOR SURFACE TREATMENT: burnished

HEIGHT (IN CM): 6.4

ORIFICE DIAMETER (IN CM): 9.1

DIAMETER AT BOTTOM OF RIM OR NECK (IN CM): 9.3

BASE DIAMETER (IN CM) AND SHAPE OF BASE: 5.2; circular and flat

ESTIMATED VOLUME (IN LITERS): 0.35

DECORATION (INCLUDING MOTIF AND ELEMENTS WHEN APPARENT): The rim panel has at least four engraved elements divided by a diagonal engraved line. The engraved elements consist of upper and lower hatched triangle elements that end in hooked arms (Figure 14).

PIGMENT USE AND LOCATION ON VESSEL: red clay pigment in the engraved lines TYPE AND VARIETY (IF KNOWN): Womack Engraved, var. Culpepper

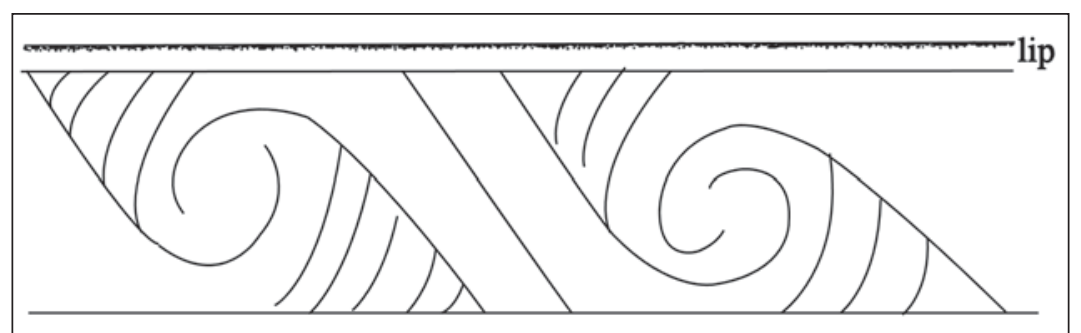

Figure 14. Womack Engraved, var. Culpepper carinated bowl (No. 6) in Burial 1 at the Culpepper site. 
SITE NAME OR SITE NUMBER: Culpepper

VESSEL NO.: 7, Burial 1

VESSEL FORM: Carinated bowl

NON-PLASTICS AND PASTE: grog

RIM AND LIP FORM: Inverted rim and rounded lip

CORE COLOR: F (fired in a reducing environment and cooled in the open air)

INTERIOR SURFACE COLOR: dark yellowish-brown; fire clouds on the rim, body, and base

EXTERIOR SURFACE COLOR: dark yellowish-brown; fire clouds on the rim and body

WALL THICKNESS (IN MM): rim, $7.0 \mathrm{~mm}$

INTERIOR SURFACE TREATMENT: smoothed

EXTERIOR SURFACE TREATMENT: burnished

HEIGHT (IN CM): 15.2

ORIFICE DIAMETER (IN CM): 20.3

DIAMETER AT BOTTOM OF RIM OR NECK (IN CM): 20.5

BASE DIAMETER (IN CM) AND SHAPE OF BASE: 7.6; circular and flat

ESTIMATED VOLUME (IN LITERS): 2.8

DECORATION (INCLUDING MOTIF AND ELEMENTS WHEN APPARENT): The rim panel has an engraved slanting scroll line repeated four times around the vessel. The slanting scroll lines are divided by brackets filled with vertical engraved lines. The upper and lower scroll fill zones have brackets and triangle elements filled with either vertical engraved hatched lines or diagonal hatched lines (Figure 15).

PIGMENT USE AND LOCATION ON VESSEL: red clay pigment in the engraved lines

TYPE AND VARIETY (IF KNOWN): Ripley Engraved, var. Gandy

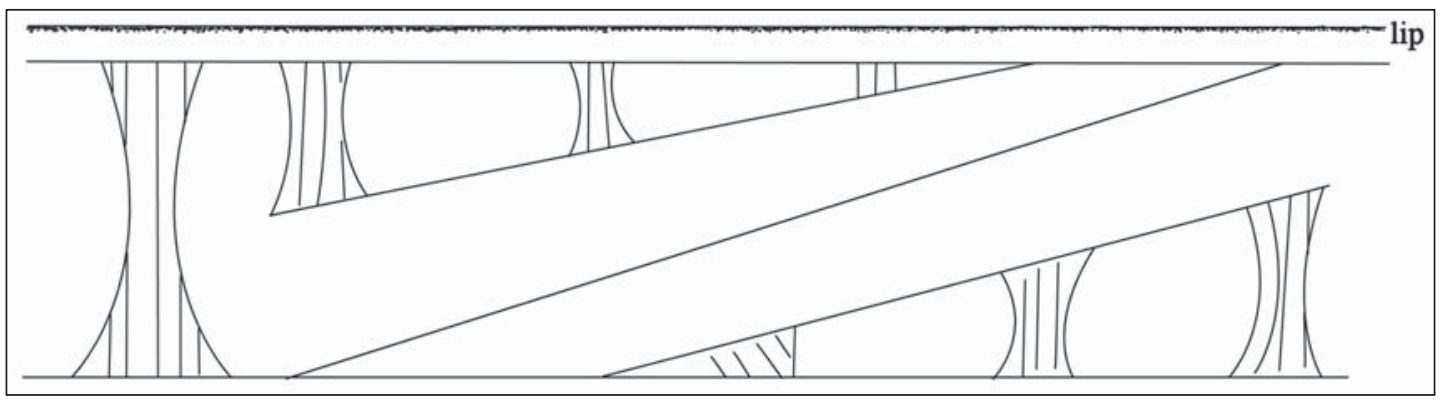

Figure 15. Decorative elements in a Ripley Engraved, var. Gandy carinated bowl (No. 7) in Burial 1 at the Culpepper site. 
SITE NAME OR SITE NUMBER: Culpepper

VESSEL NO.: 8, Burial 1

VESSEL FORM: Jar

NON-PLASTICS AND PASTE: grog

RIM AND LIP FORM: N/A

CORE COLOR: F (fired in a reducing environment and cooled in the open air)

INTERIOR SURFACE COLOR: yellowish-brown; fire clouds on the body

EXTERIOR SURFACE COLOR: yellowish-brown; fire clouds on the rim, body, and base

WALL THICKNESS (IN MM): rim, $4.5 \mathrm{~mm}$; body, $5.7 \mathrm{~mm}$

INTERIOR SURFACE TREATMENT: smoothed

EXTERIOR SURFACE TREATMENT: smoothed on the body

HEIGHT (IN CM): N/A

ORIFICE DIAMETER (IN CM): N/A

DIAMETER AT BOTTOM OF RIM OR NECK (IN CM): N/A

BASE DIAMETER (IN CM) AND SHAPE OF BASE: 6.4; circular and flat

ESTIMATED VOLUME (IN LITERS): N/A

DECORATION(INCLUDINGMOTIFANDELEMENTS WHENAPPARENT): There is at least one horizontal neck banded row on the lower part of the partial rim. The vessel body has four vertical appliqued ridges evenly spaced around the vessel that extend from the rim-body juncture to within $3.0 \mathrm{~cm}$ of the vessel base.

PIGMENT USE AND LOCATION ON VESSEL: none

TYPE AND VARIETY (IF KNOWN): La Rue Neck Banded 
SITE NAME OR SITE NUMBER: Culpepper

VESSEL NO.: 18, Burial 2

VESSEL FORM: Jar with a scalloped lip

NON-PLASTICS AND PASTE: grog

RIM AND LIP FORM: Everted rim and rounded lip

CORE COLOR: F (fired in a reducing environment and cooled in the open air)

INTERIOR SURFACE COLOR: red

EXTERIOR SURFACE COLOR: red; fire clouds on the rim and body; organic residue on the rim and body

WALL THICKNESS (IN MM): rim, $5.1 \mathrm{~mm}$; body, $6.3 \mathrm{~mm}$

INTERIOR SURFACE

TREATMENT: burnished

EXTERIOR SURFACE

TREATMENT: burnished

HEIGHT (IN CM): 12.5

ORIFICE DIAMETER

(IN CM): 13.5

DIAMETER AT BOTTOM OF

RIM OR NECK (IN CM): 13.7

BASE DIAMETER (IN CM)

AND SHAPE OF BASE:

6.4; circular and flat

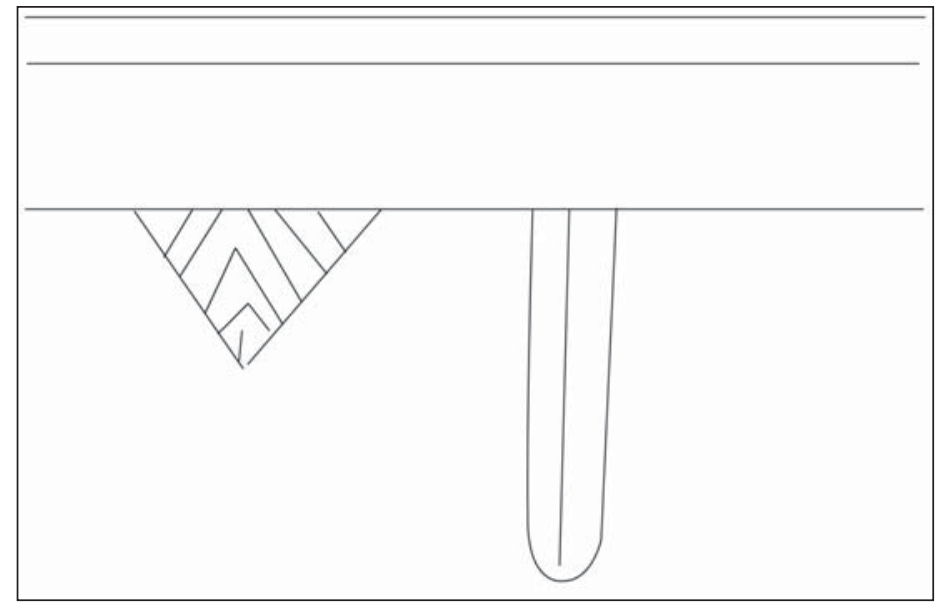

Figure 16. Decorative elements on engraved jar (No. 18) in Burial 2 at the Culpepper site.

ESTIMATED VOLUME

(IN LITERS): 1.0

DECORATION (INCLUDING MOTIF AND ELEMENTS WHEN APPARENT): The interior and exterior surfaces of the vessel have a red slip. The vessel rim has two widely-spaced horizontal engraved lines. Pendant from the horizontal engraved line at the rim-body juncture are four sets of engraved triangles filled with diagonal opposed lines and four sets of a curvilinear and vertical engraved zone with a single centrallyplaced vertical engraved line (Figure 16). The decorative elements on this vessel closely resemble several Late McCurtain (ca. A.D. 1650-1700) engraved jars from the Bob Williams (41RR16) and Rowland Clark (41RR77) sites on the middle Red River (Perino 1983, 1994:40 and Figure 16f).

PIGMENT USE AND LOCATION ON VESSEL: none

TYPE AND VARIETY (IF KNOWN): Unidentified fine ware 
SITE NAME OR SITE NUMBER: Culpepper

VESSEL NO.: 19, Burial 2

VESSEL FORM: Carinated bowl

NON-PLASTICS AND PASTE: grog

RIM AND LIP FORM: Inverted rim and rounded lip

CORE COLOR: G (fired in a reducing environment and cooled in the open air)

INTERIOR SURFACE COLOR: dark grayish-brown

EXTERIOR SURFACE COLOR: yellowish-brown; fire clouds on the rim and body

WALL THICKNESS (IN MM):

rim, $6.7 \mathrm{~mm}$; body, $7.0 \mathrm{~mm}$

INTERIOR SURFACE

TREATMENT: smoothed

EXTERIOR SURFACE

TREATMENT: burnished

HEIGHT (IN CM): 13.8

ORIFICE DIAMETER (IN CM): 21.5

DIAMETER AT BOTTOM OF

RIM OR NECK (IN CM): 21.7

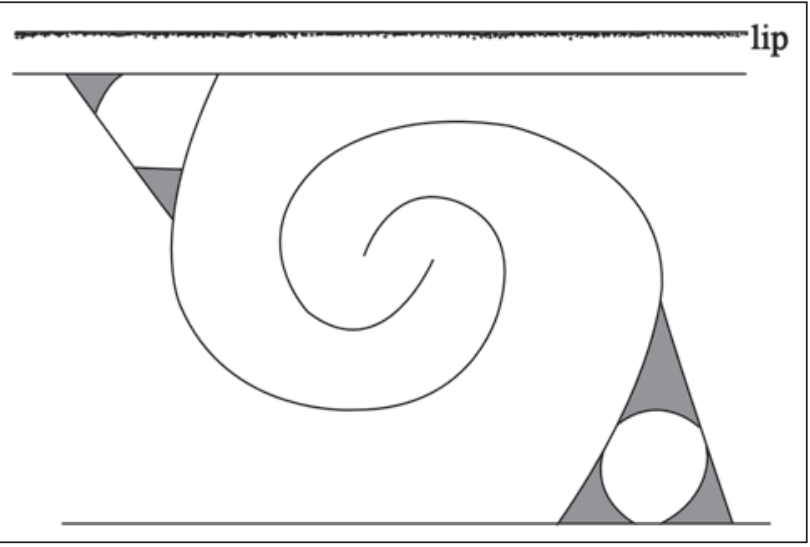

BASE DIAMETER (IN CM) AND

SHAPE OF BASE: 9.5; circular and flat

Figure 17. Decorative elements on a Wilder Engraved, var. unspecified carinated bowl (No. 19) in Burial 2 at the Culpepper site.

ESTIMATED VOLUME (IN LITERS): 2.7

DECORATION (INCLUDING MOTIF AND ELEMENTS WHEN APPARENT): The rim panel has at least seven repeating sets of engraved spirals with hooked arms that do not meet. The spirals originate from large upper and lower engraved pendant triangles with excised negative ovals inside the pendant triangles (Figure 17)

PIGMENT USE AND LOCATION ON VESSEL: none

TYPE AND VARIETY (IF KNOWN): Wilder Engraved, var. unspecified 
SITE NAME OR SITE NUMBER: Culpepper

VESSEL NO.: 20, Burial 2

VESSEL FORM: Carinated bowl

NON-PLASTICS AND PASTE: grog

RIM AND LIP FORM: Inverted rim and rounded lip

CORE COLOR: F (fired in a reducing environment and cooled in the open air)

INTERIOR SURFACE COLOR: red

EXTERIOR SURFACE COLOR: red

WALL THICKNESS (IN MM): rim, $6.2 \mathrm{~mm}$

INTERIOR SURFACE TREATMENT: smoothed

EXTERIOR SURFACE TREATMENT: burnished

HEIGHT (IN CM): 9.1

ORIFICE DIAMETER (IN CM): 14.0

DIAMETER AT BOTTOM OF RIM OR NECK (IN CM): 14.6

BASE DIAMETER (IN CM) AND SHAPE OF BASE: 7.0; circular and flat

ESTIMATED VOLUME (IN LITERS): 0.8

DECORATION (INCLUDING MOTIF AND ELEMENTS WHEN APPARENT): The interior and exterior surfaces of the vessel have a red slip. The rim panel is divided into four sections by sets of four vertical or vertical-curvilinear engraved lines. The panels have three large upper and lower excised triangles (Figure 18).

PIGMENT USE AND LOCATION ON VESSEL: none

TYPE AND VARIETY (IF KNOWN): Unidentified fine ware

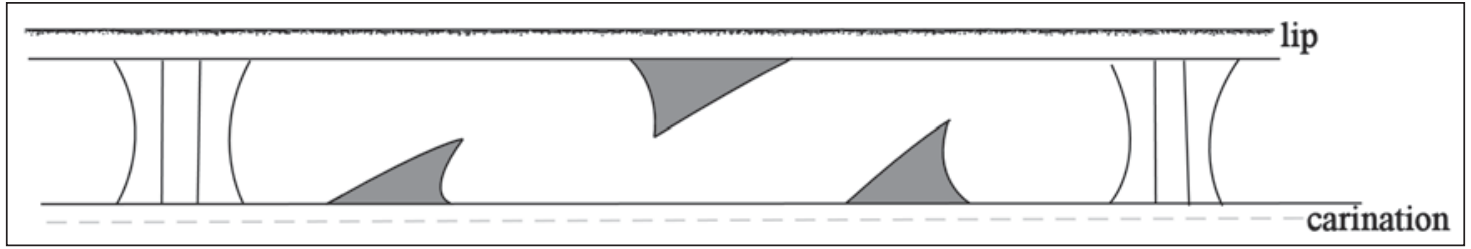

Figure 18. Decorative elements on an engraved carinated bowl (No. 20) in Burial 2 at the Culpepper site. 
SITE NAME OR SITE NUMBER: Culpepper

VESSEL NO.: 21, Burial 2

VESSEL FORM: Jar body/base section

NON-PLASTICS AND PASTE: grog

RIM AND LIP FORM: N/A

CORE COLOR: $\mathrm{G}$ (fired in a reducing environment and cooled in the open air)

INTERIOR SURFACE COLOR: dark grayish-brown

EXTERIOR SURFACE COLOR: yellowish-brown; fire clouds on the body and base; organic residue on the body

WALL THICKNESS (IN MM): body, $7.3 \mathrm{~mm}$

INTERIOR SURFACE TREATMENT: none

EXTERIOR SURFACE TREATMENT: smoothed

HEIGHT (IN CM): 10.2+

ORIFICE DIAMETER (IN CM): N/A

DIAMETER AT BOTTOM OF RIM OR NECK (IN CM): 12.1

BASE DIAMETER (IN CM) AND SHAPE OF BASE: 8.3; circular and flat

ESTIMATED VOLUME (IN LITERS): 0.7+

DECORATION (INCLUDING MOTIF AND ELEMENTS WHEN APPARENT): Plain

PIGMENT USE AND LOCATION ON VESSEL: none

TYPE AND VARIETY (IF KNOWN): Unidentified plain ware 
SITE NAME OR SITE NUMBER: Culpepper

VESSEL NO.: 22, Burial 2

VESSEL FORM: Jar section

NON-PLASTICS AND PASTE: grog

RIM AND LIP FORM: Everted rim and rounded lip

CORE COLOR: $\mathrm{F}$ (fired in a reducing environment and cooled in the open air)

INTERIOR SURFACE COLOR: yellowish-brown; fire clouds on the rim and body; organic residue on the body

EXTERIOR SURFACE COLOR: yellowish-brown; fire clouds on the rim and body; organic remains on the body

WALL THICKNESS (IN MM): rim, $6.6 \mathrm{~mm}$; body, $7.7 \mathrm{~mm}$

INTERIOR SURFACE TREATMENT: smoothed

EXTERIOR SURFACE TREATMENT: smoothed on the body

HEIGHT (IN CM): N/A; rim height is $5.1 \mathrm{~cm}$

ORIFICE DIAMETER (IN CM): 19.8

DIAMETER AT BOTTOM OF RIM OR NECK (IN CM): 19.6

BASE DIAMETER (IN CM) AND SHAPE OF BASE: N/A

ESTIMATED VOLUME (IN LITERS): N/A

DECORATION (INCLUDING MOTIF AND ELEMENTS WHEN APPARENT): There are four horizontal neck banded rows on the vessel rim.

PIGMENT USE AND LOCATION ON VESSEL: none

TYPE AND VARIETY (IF KNOWN): La Rue Neck Banded 
SITE NAME OR SITE NUMBER: Culpepper

VESSEL NO.: 23, Burial 3

VESSEL FORM: Carinated bowl

NON-PLASTICS AND PASTE: grog

RIM AND LIP FORM: Inverted rim and rounded lip

CORE COLOR: A (fired and cooled in an oxidizing environment)

INTERIOR SURFACE COLOR: light yellowish-brown; fire clouds on the body and base

EXTERIOR SURFACE COLOR: light yellowish-brown; fire clouds on the rim and body

WALL THICKNESS (IN MM): rim, $6.2 \mathrm{~mm}$; body, $7.0 \mathrm{~mm}$

INTERIOR SURFACE TREATMENT: smoothed

EXTERIOR SURFACE TREATMENT: smoothed

HEIGHT (IN CM): 16.5

ORIFICE DIAMETER (IN CM): 25.4

DIAMETER AT BOTTOM OF RIM OR NECK (IN CM): 25.6

BASE DIAMETER (IN CM) AND SHAPE OF BASE: 11.5; circular and flat

ESTIMATED VOLUME (IN LITERS): 3.7

DECORATION (INCLUDING MOTIF AND ELEMENTS WHEN APPARENT): The rim panel has four repeating sets of an engraved slanted scroll and circle motif. The central circle element has within it a smaller engraved diamond element. The upper and lower scroll fill zones have brackets and triangle elements filled with cross-hatched engraved lines (Figure 19).

PIGMENT USE AND LOCATION ON VESSEL: none

TYPE AND VARIETY (IF KNOWN): Ripley Engraved, var. Galt

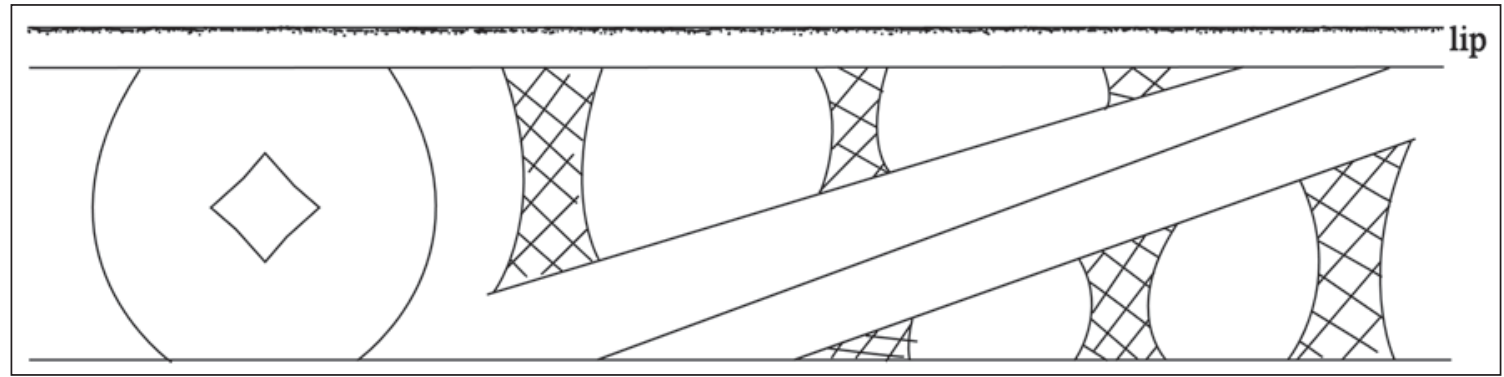

Figure 19. Decorative elements on Ripley Engraved, var. Galt carinated bowl (No. 23) in Burial 3 at the Culpepper site. 
SITE NAME OR SITE NUMBER: Culpepper

VESSEL NO.: 25, Burial 3

VESSEL FORM: Jar

NON-PLASTICS AND PASTE: grog

RIM AND LIP FORM: Everted rim and rounded lip

CORE COLOR: F (fired in a reducing environment and cooled in the open air)

INTERIOR SURFACE

COLOR: yellowish-brown;

fire clouds on the rim and body

EXTERIOR SURFACE

COLOR: yellowish-brown;

fire clouds on the rim and body

WALL THICKNESS (IN MM):

rim, $7.0 \mathrm{~mm}$; body, $8.1 \mathrm{~mm}$

INTERIOR SURFACE

TREATMENT: none

EXTERIOR SURFACE

TREATMENT: none

HEIGHT (IN CM): N/A

ORIFICE DIAMETER (IN CM): 26.0

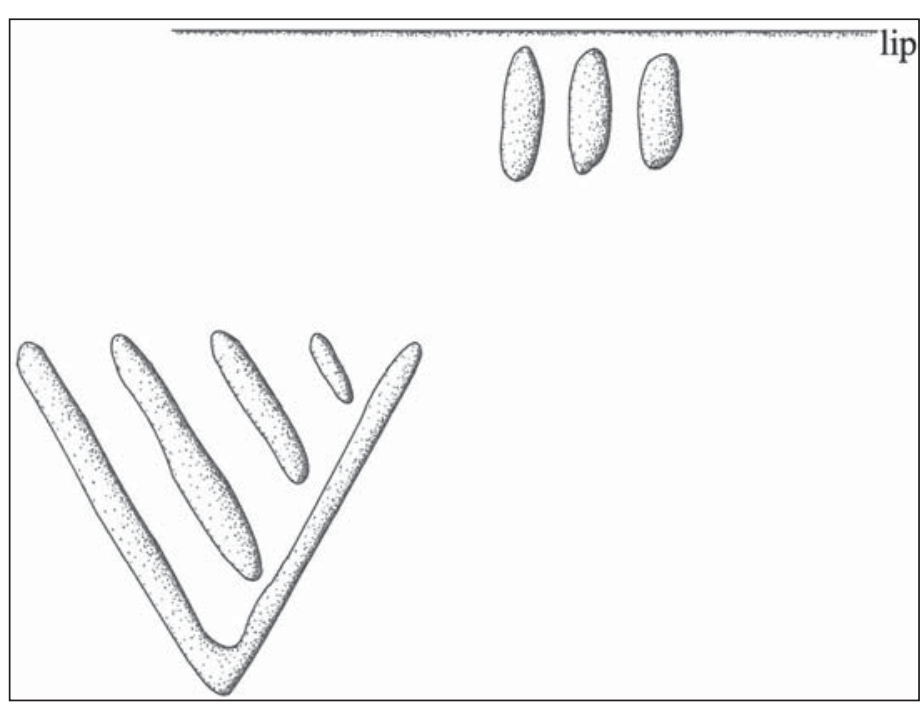

Figure 20. Decorative elements on a Harleton Appliqued jar (No. 25) in Burial 3 at the Culpepper site.

DIAMETER AT BOTTOM OF RIM OR NECK (IN CM): 25.2

BASE DIAMETER (IN CM) AND SHAPE OF BASE: N/A

ESTIMATED VOLUME (IN LITERS): N/A

DECORATION (INCLUDING MOTIF AND ELEMENTS WHEN APPARENT): The rim has four closelyspaced sets of three short vertical appliqued ridges or lugs. The vessel body has four sets of appliqued ridge chevron elements. The chevrons are formed by two diagonal opposed appliqued ridges, and within the appliqued chevron are three increasingly longer diagonal (pitched from left to right) appliqued ridges (Figure 20).

PIGMENT USE AND LOCATION ON VESSEL: none

TYPE AND VARIETY (IF KNOWN): Harleton Appliqued 
SITE NAME OR SITE NUMBER: Culpepper

VESSEL NO.: 26, Burial 3

VESSEL FORM: Carinated bowl

NON-PLASTICS AND PASTE: grog

RIM AND LIP FORM: Inverted rim and rounded lip

CORE COLOR: F (fired in a reducing environment and cooled in the open air)

INTERIOR SURFACE COLOR: red

EXTERIOR SURFACE COLOR: red

WALL THICKNESS (IN MM): rim, $5.8 \mathrm{~mm}$; body, $5.4 \mathrm{~mm}$

INTERIOR SURFACE TREATMENT: smoothed

EXTERIOR SURFACE TREATMENT: burnished

HEIGHT (IN CM): 9.5

ORIFICE DIAMETER (IN CM): 13.5

DIAMETER AT BOTTOM OF RIM OR NECK (IN CM): 13.7

BASE DIAMETER (IN CM) AND SHAPE OF BASE: 6.4; circular and flat

ESTIMATED VOLUME (IN LITERS): 0.8

DECORATION (INCLUDING MOTIF AND ELEMENTS WHEN APPARENT): The rim panel has four repeated sets of a slanting scroll and circle engraved motif. Within the circles is a centrally-placed engraved diamond element. The upper and lower scroll fill zones have excised brackets and triangles as well as large open (or partially excised) pendant triangles (Figure 21).

PIGMENT USE AND LOCATION ON VESSEL: none

TYPE AND VARIETY (IF KNOWN): Ripley Engraved, var. Galt

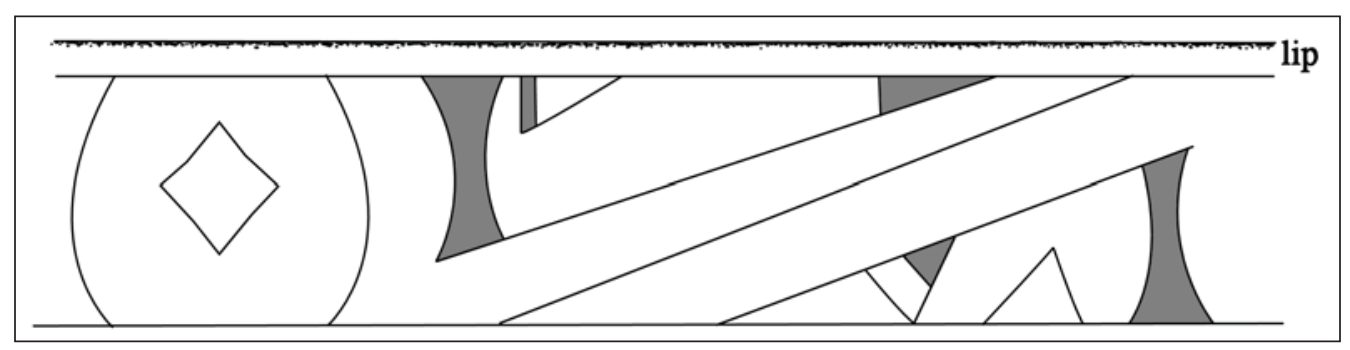

Figure 21. Decorative elements on a Ripley Engraved, var. Galt carinated bowl (No. 26) in Burial 3 at the Culpepper site. 
SITE NAME OR SITE NUMBER: Culpepper

VESSEL NO.: 31, Burial 5

VESSEL FORM: Carinated bowl

NON-PLASTICS AND PASTE: grog

RIM AND LIP FORM: Inverted rim and rounded lip

CORE COLOR: B (fired and cooled in a reducing environment)

INTERIOR SURFACE COLOR: grayish-brown; fire clouds on the rim

EXTERIOR SURFACE COLOR: grayish-brown; fire clouds on the rim and body

WALL THICKNESS (IN MM): rim, $7.6 \mathrm{~mm}$

INTERIOR SURFACE TREATMENT: burnished on the rim and smoothed on the body

EXTERIOR SURFACE TREATMENT: burnished

HEIGHT (IN CM): 15.0

ORIFICE DIAMETER (IN CM): 23.0

DIAMETER AT BOTTOM OF RIM OR NECK (IN CM): 23.4

BASE DIAMETER (IN CM) AND SHAPE OF BASE: 8.9; circular and flat

ESTIMATED VOLUME (IN LITERS): 3.1

DECORATION (INCLUDING MOTIF AND ELEMENTS WHEN APPARENT): The rim panel has three sets of two interlocking horizontal and curvilinear engraved scroll lines. The scrolls are connected to upper and lower horizontal engraved lines - that define the rim panel — by two excised brackets (Figure 22).

PIGMENT USE AND LOCATION ON VESSEL: none

TYPE AND VARIETY (IF KNOWN): Ripley Engraved, var. Pilgrims

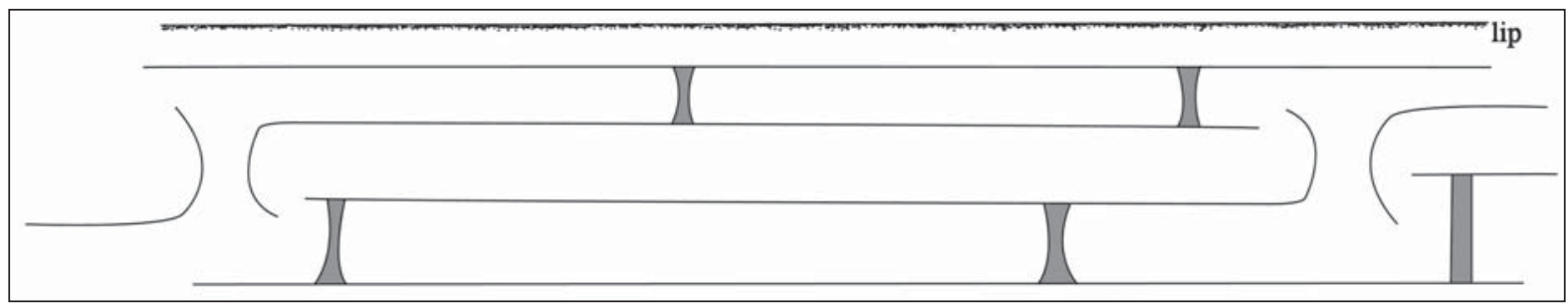

Figure 22. Decorative elements on a Ripley Engraved, var. Pilgrims carinated bowl (No. 31) in Burial 5 at the Culpepper site. 
SITE NAME OR SITE NUMBER: Culpepper

VESSEL NO.: 32, Burial 5

VESSEL FORM: Bottle with a spool neck

NON-PLASTICS AND PASTE: grog

RIM AND LIP FORM: Everted and direct rim and exterior folded lip

CORE COLOR: B (fired and cooled in a reducing environment)

INTERIOR SURFACE COLOR:

very dark grayish-brown

EXTERIOR SURFACE COLOR:

very dark grayish-brown; fire clouds

on the body and base

WALL THICKNESS (IN MM):

rim, $6.5 \mathrm{~mm}$

INTERIOR SURFACE

TREATMENT: none

EXTERIOR SURFACE

TREATMENT: burnished

HEIGHT (IN CM): 15.2

ORIFICE DIAMETER (IN CM): 4.6

DIAMETER AT BOTTOM OF RIM

OR NECK (IN CM): 4.9; maximum

body diameter is $10.8 \mathrm{~cm}$

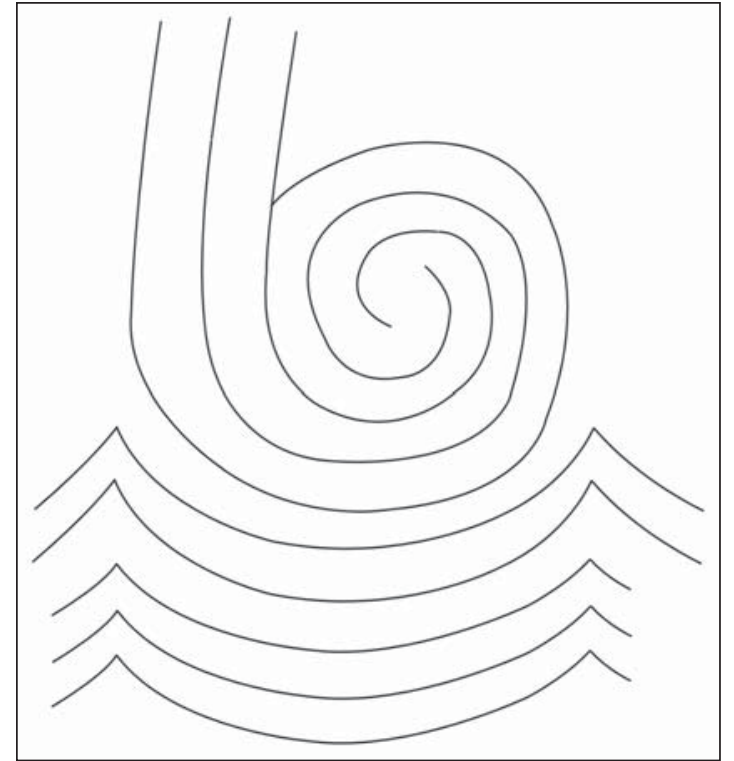

Figure 23. Decorative elements on a Taylor Engraved bottle (No. 32) in Burial 5 at the Culpepper site.

BASE DIAMETER (IN CM) AND SHAPE OF BASE: 5.7; circular and rounded

ESTIMATED VOLUME (IN LITERS): 0.35

DECORATION (INCLUDING MOTIF AND ELEMENTS WHEN APPARENT): The vessel body has four upper and lower sets of engraved motifs. The upper set consist of engraved spirals, comprised of three lines, that end in a hooked arm element. The lower set consists of five sets of curvilinear engraved lines (Figure 23); from below, they form a square shape that outlines the vessel base.

PIGMENT USE AND LOCATION ON VESSEL: red clay pigment in the engraved lines TYPE AND VARIETY (IF KNOWN): Taylor Engraved 
SITE NAME OR SITE NUMBER: Culpepper

VESSEL NO.: 35, Burial 5

VESSEL FORM: Jar

NON-PLASTICS AND PASTE: shell

RIM AND LIP FORM: Everted rim and rounded lip

CORE COLOR: F (fired in a reducing environment and cooled in the open air)

INTERIOR SURFACE COLOR: red

EXTERIOR SURFACE COLOR: red

WALL THICKNESS (IN MM): rim, 6.4 mm

INTERIOR SURFACE TREATMENT: smoothed

EXTERIOR SURFACE TREATMENT: burnished

HEIGHT (IN CM): 20.5

ORIFICE DIAMETER (IN CM): 21.5

DIAMETER AT BOTTOM OF RIM OR NECK (IN CM): 20.1

BASE DIAMETER (IN CM) AND SHAPE OF BASE: 9.4; circular and flat

ESTIMATED VOLUME (IN LITERS): 4.0

DECORATION (INCLUDING MOTIF AND ELEMENTS WHEN APPARENT): The interior and exterior vessel surfaces have a red slip. The rim panel has four sets of engraved spirals that end in a hooked arm element. Between these spirals are four sets of three concentric semi-circular lines. The lowermost line encloses a semi-circle with vertical hatched lines. The second semi-circular line has a series of excised triangular tick marks, while the third semi-circular line encloses a zone with a series of vertical-curvilinear lines and one narrow excised vertical column (Figure 24).

PIGMENT USE AND LOCATION ON VESSEL: none

TYPE AND VARIETY (IF KNOWN): Taylor Engraved

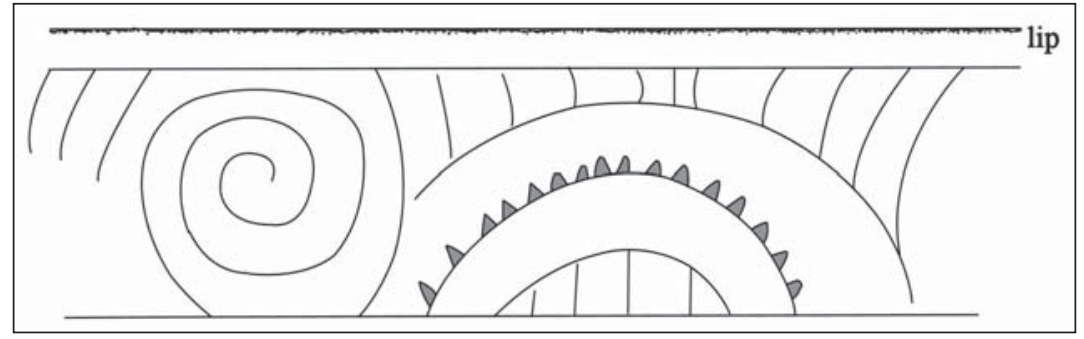

Figure 24. Decorative elements on a Taylor Engraved jar (No. 35) in Burial 5 at the Culpepper site. 
SITE NAME OR SITE NUMBER: Culpepper

VESSEL NO.: 36, Burial 6

VESSEL FORM: Carinated bowl

NON-PLASTICS AND PASTE: grog

RIM AND LIP FORM: Inverted rim and rounded lip

CORE COLOR: F (fired in a reducing environment and cooled in the open air)

INTERIOR SURFACE COLOR: yellowish-brown; fire clouds on the rim, body, and base

EXTERIOR SURFACE COLOR: yellowish-brown; fire clouds on the rim and body

WALL THICKNESS (IN MM): rim, $6.7 \mathrm{~mm}$

INTERIOR SURFACE TREATMENT: smoothed

EXTERIOR SURFACE TREATMENT: burnished

HEIGHT (IN CM): 13.4

ORIFICE DIAMETER (IN CM): 21.5

DIAMETER AT BOTTOM OF RIM OR NECK (IN CM): 21.8

BASE DIAMETER (IN CM) AND SHAPE OF BASE: 8.3; circular and flat

ESTIMATED VOLUME (IN LITERS): 2.6

DECORATION(INCLUDING MOTIFAND ELEMENTS WHENAPPARENT): The rim panel has a repeating set of 10 engraved motifs comprised of upper and lower slanting lines that begin at the end of hatched triangle elements, spiral around each other, and end in hooked arm elements. Six of the engraved spiral/hooked arm elements end in small excised dots. The engraved spiral/hooked arm elements are divided from each other by a single left to right-oriented diagonal engraved line (Figure 25).

PIGMENT USE AND LOCATION ON VESSEL: red clay pigment in the engraved lines

TYPE AND VARIETY (IF KNOWN): Womack Engraved, var. Culpepper

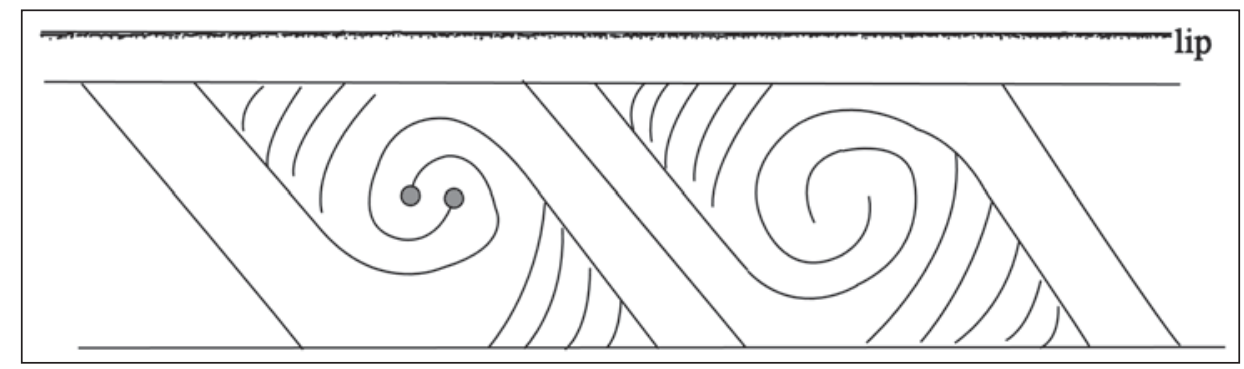

Figure 25. Decorative elements on a Womack Engraved, var. Culpepper carinated bowl (No. 36) in Burial 6 at the Culpepper site. 
SITE NAME OR SITE NUMBER: Culpepper

VESSEL NO.: 37, Burial 6

VESSEL FORM: Carinated bowl

NON-PLASTICS AND PASTE: grog

RIM AND LIP FORM: Inverted rim and flat, exterior folded, lip

CORE COLOR: F (fired in a reducing environment and cooled in the open air)

INTERIOR SURFACE COLOR: yellowish-brown; fire clouds on the rim

EXTERIOR SURFACE COLOR: yellowish-brown; fire clouds on the rim, body, and base

WALL THICKNESS (IN MM): rim, $6.3 \mathrm{~mm}$; body, $6.9 \mathrm{~mm}$

INTERIOR SURFACE TREATMENT: smoothed

EXTERIOR SURFACE TREATMENT: burnished

HEIGHT (IN CM): 15.2

ORIFICE DIAMETER (IN CM): 19.1

DIAMETER AT BOTTOM OF RIM OR NECK (IN CM): 19.4

BASE DIAMETER (IN CM) AND SHAPE OF BASE: 8.3; circular and flat

ESTIMATED VOLUME (IN LITERS): 2.6

DECORATION (INCLUDING MOTIF AND ELEMENTS WHEN APPARENT): The rim panel has an assortment of engraved elements with no particular consistency or pattern. There are hatched vertical columns, curvilinear and vertical engraved lines, a circular element with a central excised dot, and a series of semicircles attached to the upper part of the rim panel by vertical or diagonal lines (Figure 26).

PIGMENT USE AND LOCATION ON VESSEL: none

TYPE AND VARIETY (IF KNOWN): Unidentified fine ware

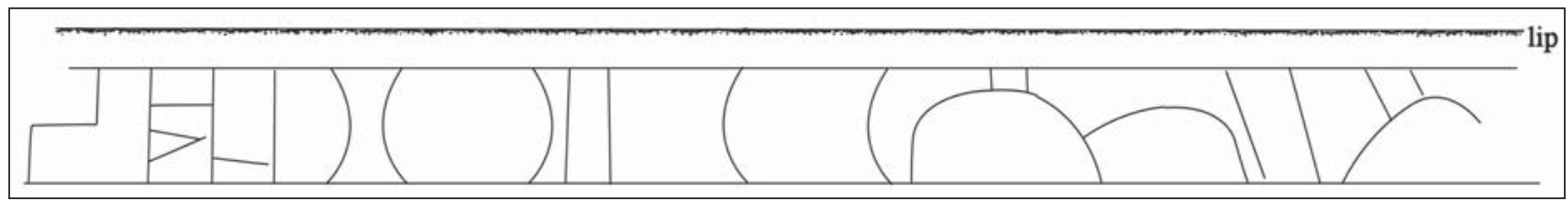

Figure 26. Decorative elements on an engraved carinated bowl (No. 37) in Burial 6 at the Culpepper site. 
SITE NAME OR SITE NUMBER: Culpepper

VESSEL NO.: 38, Burial 6

VESSEL FORM: Jar

NON-PLASTICS AND PASTE: shell

RIM AND LIP FORM: Everted rim and rounded lip

CORE COLOR: $\mathrm{F}$ (fired in a reducing environment and cooled in the open air)

INTERIOR SURFACE COLOR: red

EXTERIOR SURFACE COLOR: red

WALL THICKNESS (IN MM): rim, $4.2 \mathrm{~mm}$

INTERIOR SURFACE TREATMENT: burnished

EXTERIOR SURFACE TREATMENT: burnished

HEIGHT (IN CM): 8.9

ORIFICE DIAMETER (IN CM): 11.5

DIAMETER AT BOTTOM OF RIM OR NECK (IN CM): 9.9

BASE DIAMETER (IN CM) AND SHAPE OF BASE: 4.3; circular and flat

ESTIMATED VOLUME (IN LITERS): 0.6

DECORATION (INCLUDING MOTIF AND ELEMENTS WHEN APPARENT): The rim panel has five sets of slanting engraved scrolls that end in hooked arm elements. The upper and lower scroll fill zones are triangular-shaped and filled with vertical hatched lines (Figure 27).

PIGMENT USE AND LOCATION ON VESSEL: white clay pigment in the engraved lines TYPE AND VARIETY (IF KNOWN): Taylor Engraved

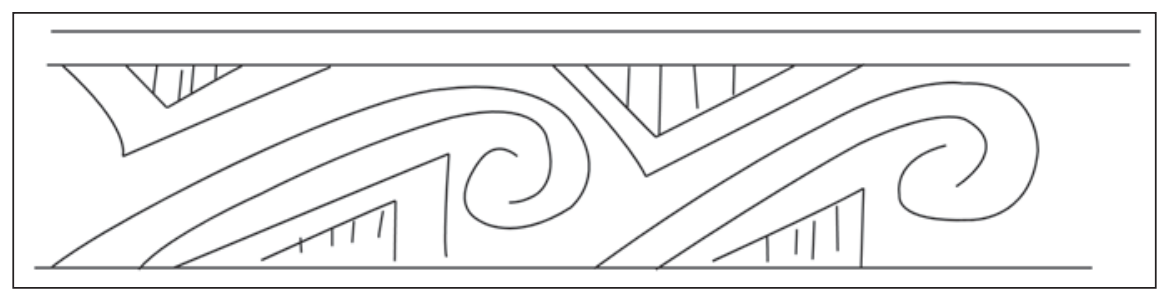

Figure 27. Decorative elements on a Taylor Engraved jar (No. 38) in Burial 6 at the Culpepper site. 
SITE NAME OR SITE NUMBER: Culpepper

VESSEL NO.: 39, Burial 6

VESSEL FORM: Bottle with a spool neck and a pedestal base

NON-PLASTICS AND PASTE: shell

RIM AND LIP FORM: Everted to direct rim and a rounded lip

CORE COLOR: B (fired and cooled in a reducing environment)

INTERIOR SURFACE COLOR: very dark grayish-brown

EXTERIOR SURFACE COLOR: very dark grayish-brown; fire clouds on the rim and body

WALL THICKNESS (IN MM):

rim, $5.7 \mathrm{~mm}$

INTERIOR SURFACE

TREATMENT: none

EXTERIOR SURFACE

TREATMENT: burnished

HEIGHT (IN CM): 15.8

ORIFICE DIAMETER (IN CM): 5.1

DIAMETER AT BOTTOM OF

RIM OR NECK (IN CM): 4.6;

maximum body diameter is $11.9 \mathrm{~cm}$

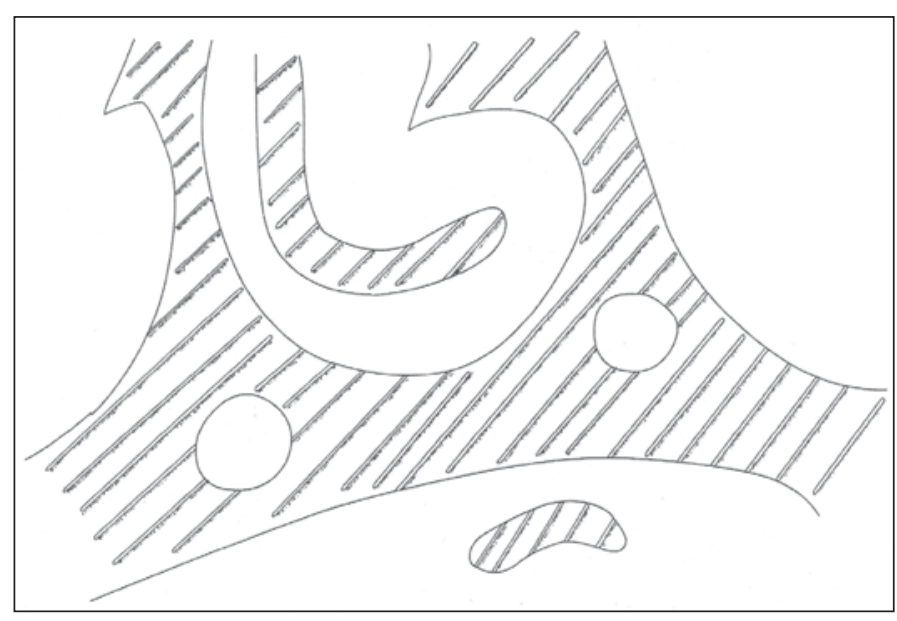

Figure 28. Decorative elements on a Hudson Engraved bottle (No. 39) in Burial 6 at the Culpepper site.

BASE DIAMETER (IN CM) AND

SHAPE OF BASE: 4.5 ; circular and flat

ESTIMATED VOLUME (IN LITERS): 0.28

DECORATION (INCLUDING MOTIF AND ELEMENTS WHEN APPARENT): The vessel body has three repeating small curvilinear engraved elements filled with diagonal incised lines. These elements are surrounded by a large curvilinear engraved zone across the vessel that is also filled with diagonal incised lines; the zone also has within it three negative circles (Figure 28).

PIGMENT USE AND LOCATION ON VESSEL: none

TYPE AND VARIETY (IF KNOWN): Hudson Engraved 
SITE NAME OR SITE NUMBER: Culpepper

VESSEL NO.: 40, Burial 6

VESSEL FORM: Carinated bowl

NON-PLASTICS AND PASTE: grog

RIM AND LIP FORM: Inverted rim and rounded lip

CORE COLOR: $\mathrm{G}$ (fired in a reducing environment and cooled in the open air)

INTERIOR SURFACE COLOR: grayish-brown

EXTERIOR SURFACE COLOR: yellowish-brown; fire clouds on the rim, body, and base

WALL THICKNESS (IN MM): rim, $8.6 \mathrm{~mm}$

INTERIOR SURFACE TREATMENT: smoothed

EXTERIOR SURFACE TREATMENT: burnished

HEIGHT (IN CM): 14.4

ORIFICE DIAMETER (IN CM): 21.9

DIAMETER AT BOTTOM OF RIM OR NECK (IN CM): 22.8

BASE DIAMETER (IN CM) AND SHAPE OF BASE: 8.9; circular and flat

ESTIMATED VOLUME (IN LITERS): 2.8

DECORATION(INCLUDING MOTIFAND ELEMENTS WHENAPPARENT): The rim panel has a repeating set of 11 engraved motifs comprised of upper and lower slanting lines that begin at the end of hatched triangle elements, spiral around each other, and end in hooked arm elements. Six of the engraved spiral/hooked arm elements end in small excised dots or circles. The engraved spiral/hooked arm elements are divided from each other by a single left to right-oriented diagonal engraved line (Figure 29).

PIGMENT USE AND LOCATION ON VESSEL: red clay pigment in the engraved lines

TYPE AND VARIETY (IF KNOWN): Womack Engraved, var. Culpepper

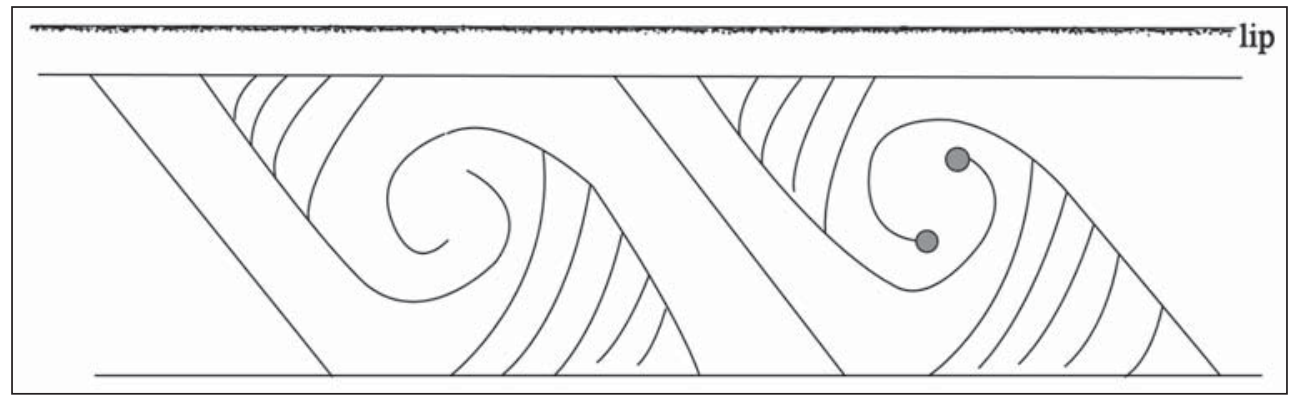

Figure 29. Decorative elements on a Womack Engraved, var. Culpepper carinated bowl (No. 40) in Burial 6 at the Culpepper site. 
SITE NAME OR SITE NUMBER: Culpepper

VESSEL NO.: 41, Burial 6

VESSEL FORM: Carinated bowl

NON-PLASTICS AND PASTE: grog

RIM AND LIP FORM: Inverted and direct rim and rounded lip; lip notched

CORE COLOR: B (fired and cooled in a reducing environment)

INTERIOR SURFACE COLOR: dark grayish-brown; fire clouds on the rim

EXTERIOR SURFACE COLOR: dark grayish-brown; fire clouds on the rim and body

WALL THICKNESS (IN MM): rim, $3.9 \mathrm{~mm}$; body, $4.3 \mathrm{~mm}$

INTERIOR SURFACE TREATMENT: smoothed

EXTERIOR SURFACE TREATMENT: burnished

HEIGHT (IN CM): 7.2

ORIFICE DIAMETER (IN CM): 10.4

DIAMETER AT BOTTOM OF RIM OR NECK (IN CM): 11.0

BASE DIAMETER (IN CM) AND SHAPE OF BASE: 4.3; circular and rounded

ESTIMATED VOLUME (IN LITERS): 0.45

DECORATION (INCLUDING MOTIF AND ELEMENTS WHEN APPARENT): The lower part of the rim panel has four sets of diagonal and diagonal opposed engraved lines with downward-pointing excised tick marks. These diagonal and diagonal opposed engraved lines are divided by four sets of four curvilinearvertical engraved lines (Figure 30.).

PIGMENT USE AND LOCATION ON VESSEL: red clay pigment in the engraved lines

TYPE AND VARIETY (IF KNOWN): Simms Engraved, var. Darco

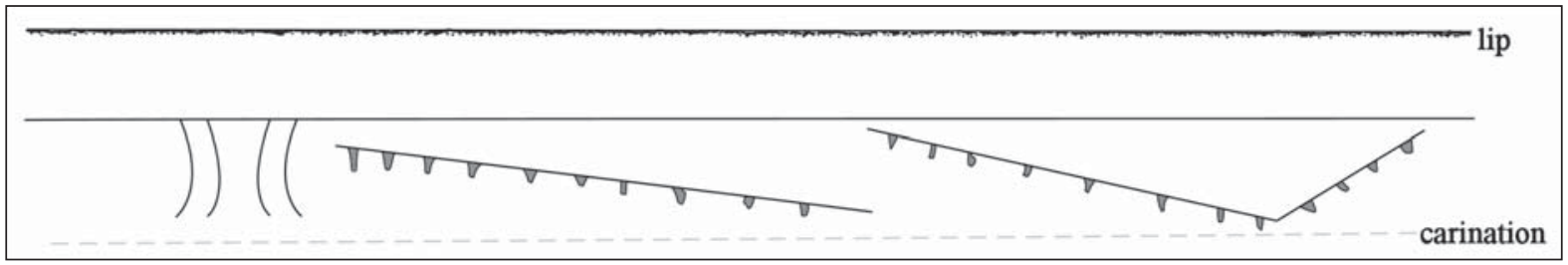

Figure 30. Decorative elements on a Simms Engraved, var. Darco carinated bowl (No. 41) in Burial 6 at the Culpepper site. 
SITE NAME OR SITE NUMBER: Culpepper

VESSEL NO.: 42, Burial 6

VESSEL FORM: Bowl

NON-PLASTICS AND PASTE: shell

RIM AND LIP FORM: Everted rim and rounded lip

CORE COLOR: F (fired in a reducing environment and cooled in the open air)

INTERIOR SURFACE COLOR: dark reddish-brown; fire clouds on the body and base

EXTERIOR SURFACE COLOR: dark reddish-brown; fire clouds on the body

WALL THICKNESS

(IN MM): rim, $4.0 \mathrm{~mm}$

INTERIOR SURFACE

TREATMENT: burnished

EXTERIOR SURFACE

TREATMENT: burnished

HEIGHT (IN CM): 10.2

ORIFICE DIAMETER

(IN CM): 16.5

DIAMETER AT BOTTOM

OF RIM OR NECK

(IN CM): N/A

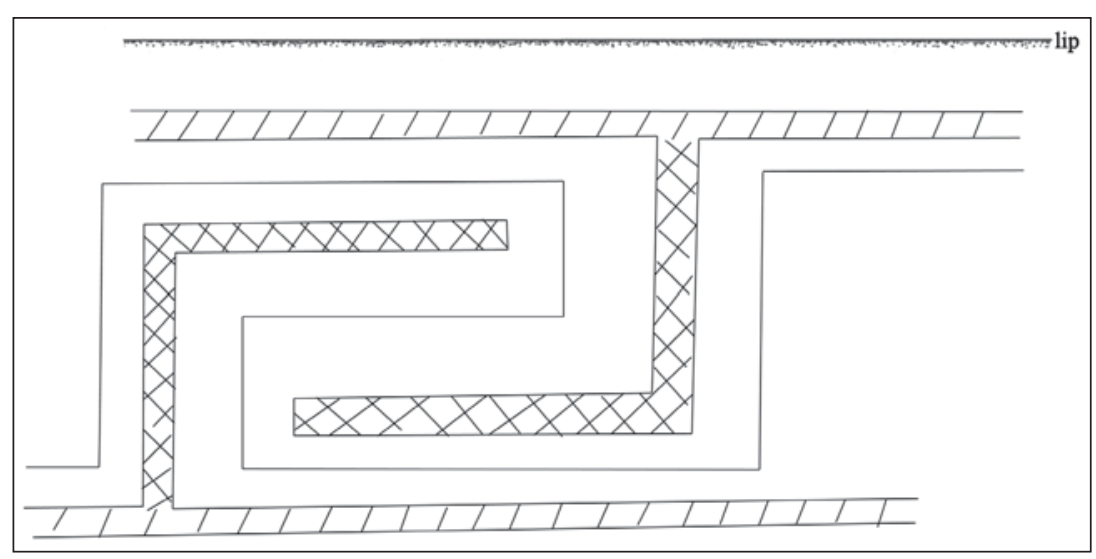

Figure 31. Decorative elements on an engraved bowl (No. 42) in Burial 6 at the Culpepper site.

BASE DIAMETER (IN CM) AND SHAPE OF BASE: 6.4; circular and rounded

ESTIMATED VOLUME (IN LITERS): 0.7

DECORATION (INCLUDING MOTIF AND ELEMENTS WHEN APPARENT): The vessel has a series of four horizontal and vertical zones filled with cross-hatched engraved lines, and these zones are divided from each other by a single continuous horizontal and vertical engraved line. Above and below these horizontal and vertical engraved zones and lines are narrow upper and lower zones filled with diagonal hatched lines (Figure 31).

PIGMENT USE AND LOCATION ON VESSEL: none

TYPEANDVARIETY (IF KNOWN): Unidentified fine ware; the vessel decorative elements resemble Barkman Engraved (see Suhm and Jelks 1962:7 and Plate 4), but Barkman Engraved vessels are not shell-tempered. 
SITE NAME OR SITE NUMBER: Culpepper

VESSEL NO.: 45A, Burial 7

VESSEL FORM: Carinated bowl

NON-PLASTICS AND PASTE: grog

RIM AND LIP FORM: Inverted rim and rounded lip

CORE COLOR: F (fired in a reducing environment and cooled in the open air)

INTERIOR SURFACE COLOR: red

EXTERIOR SURFACE COLOR: red

WALL THICKNESS (IN MM): rim, $5.6 \mathrm{~mm}$; body, $6.6 \mathrm{~mm}$

INTERIOR SURFACE TREATMENT: burnished

EXTERIOR SURFACE TREATMENT: burnished

HEIGHT (IN CM): N/A

ORIFICE DIAMETER (IN CM): 21.7

DIAMETER AT BOTTOM OF RIM OR NECK (IN CM): 22.0

BASE DIAMETER (IN CM) AND SHAPE OF BASE: N/A

ESTIMATED VOLUME (IN LITERS): N/A

DECORATION (INCLUDING MOTIF AND ELEMENTS WHEN APPARENT): The rim panel has an unknown number of engraved slanting scroll motifs, and because of vessel breakage it is not known if there was a primary element dividing the scroll motifs from one another, or what that primary element may have been. It is suspected that the primary element dividing the slanting scrolls was an engraved bracket, given the frequency of this element in the Ripley Engraved, var. Gandy carinated bowls in this vessel assemblage. The upper and lower scroll fill zones have excised brackets and excised triangle elements.

PIGMENT USE AND LOCATION ON VESSEL: white clay pigment in the engraved lines

TYPE AND VARIETY (IF KNOWN): Ripley Engraved, var. unspecified, but probably var. Gandy

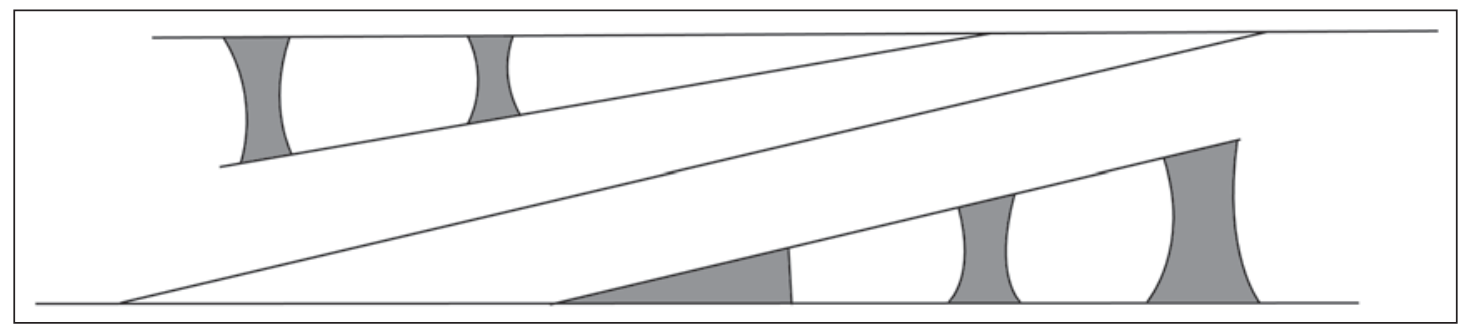

Figure 32. Decorative elements on a Ripley Engraved, var. unspecified or var. Gandy carinated bowl (No. 45A) in Burial 7 at the Culpepper site. 
SITE NAME OR SITE NUMBER: Culpepper

VESSEL NO.: 48, Burial 7

VESSEL FORM: Jar

NON-PLASTICS AND PASTE: grog

RIM AND LIP FORM: Everted rim and rounded lip

CORE COLOR: $\mathrm{G}$ (fired in a reducing environment and cooled in the open air)

INTERIOR SURFACE COLOR: dark grayish-brown; fire clouds on the rim

EXTERIOR SURFACE COLOR: reddish-brown; fire clouds on the rim, body, and base

WALL THICKNESS (IN MM): rim, $7.6 \mathrm{~mm}$; body, $7.7 \mathrm{~mm}$

INTERIOR SURFACE TREATMENT: none

EXTERIOR SURFACE TREATMENT: smoothed on the body

HEIGHT (IN CM): 22.1

ORIFICE DIAMETER (IN CM): 23.4

DIAMETER AT BOTTOM OF RIM OR NECK (IN CM): 22.6

BASE DIAMETER (IN CM) AND SHAPE OF BASE: 8.9; circular and flat

ESTIMATED VOLUME (IN LITERS): 4.6

DECORATION (INCLUDING MOTIF AND ELEMENTS WHEN APPARENT): The rim of the vessel has three horizontal neck banded rows. The vessel body has four vertical appliqued ridges that extend from the rim-body juncture to within $8.2 \mathrm{~cm}$ of the vessel base.

PIGMENT USE AND LOCATION ON VESSEL: none

TYPE AND VARIETY (IF KNOWN): La Rue Neck Banded 
SITE NAME OR SITE NUMBER: Culpepper

VESSEL NO.: No number

VESSEL FORM: Carinated bowl

NON-PLASTICS AND PASTE: grog

RIM AND LIP FORM: Inverted rim and flat lip

CORE COLOR: F (fired in a reducing environment and cooled in the open air)

INTERIOR SURFACE COLOR: yellowish-brown; fire clouds on the rim and body

EXTERIOR SURFACE COLOR: yellowish-brown; fire clouds on the rim and body

WALL THICKNESS (IN MM): rim, $6.6 \mathrm{~mm}$; body, $7.3 \mathrm{~mm}$

INTERIOR SURFACE TREATMENT: smoothed

EXTERIOR SURFACE TREATMENT: burnished

HEIGHT (IN CM): N/A; the rim panel is $3.7 \mathrm{~cm}$ in height

ORIFICE DIAMETER (IN CM): 17.8

DIAMETER AT BOTTOM OF RIM OR NECK (IN CM): N/A

BASE DIAMETER (IN CM) AND SHAPE OF BASE: N/A

ESTIMATED VOLUME (IN LITERS): N/A

DECORATION (INCLUDING MOTIF AND ELEMENTS WHEN APPARENT): The rim panel has four repeating sets of an engraved slanting scroll motif. The upper and lower parts of the slanting scrolls end in excised triangle elements. The scrolls are divided from each by excised brackets. The upper and lower scroll fill zones have excised brackets and excised triangle elements (Figure 33).

PIGMENT USE AND LOCATION ON VESSEL: none

TYPE AND VARIETY (IF KNOWN): Ripley Engraved, var. Gandy

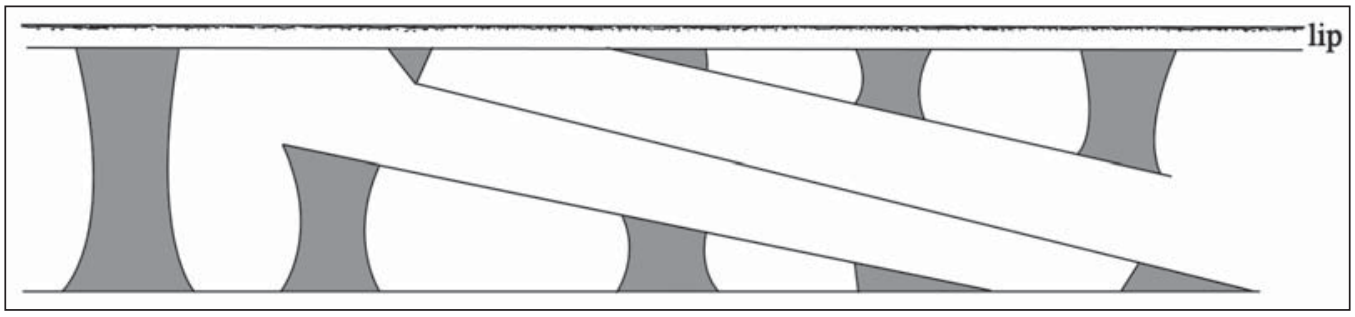

Figure 33. Decorative elements on a Ripley Engraved, var. Gandy carinated bowl (No Number) from the Culpepper site. 


\section{Summary and Conclusions}

The Culpepper site (41HP1) in the upper Sulphur River basin has an ancestral Caddo cemetery of $17^{\text {th }}$ century age that was excavated by UT archaeologists in 1931. These burials had a number of associated ceramic vessel funerary offerings, and the vessels now at TARL are documented in this article.

Based on the vessels associated with the different burials at the Culpepper site, there are apparently two different groups of burials, one group perhaps slightly older than the other. The first, and likely the older, group of burials includes Burials 3 and 7 in the west-central part of the knoll (see Figure 3). These two burials have Harleton Appliqued and La Rue Neck Banded jars and Ripley Engraved, var. Galt and var. Gandy carinated bowls. The second, and later, group of burials includes Burials 1, 2, 5, and 6 in the far northern and southern ends of the cemetery (see Figure 3). These burials have La Rue Neck Banded jars and a wide variety of fine ware bottles, carinated bowls, and jars of the following types: Hudson Engraved, Simms Engraved, Simms Engraved, var. Darco, Taylor Engraved, Wilder Engraved, var. unspecified, Womack Engraved, var. Culpepper, and Ripley Engraved, var. Carpenter, var. Gandy, and var. Pilgrims; they also include an engraved jar found in ca. A.D. 1650-1700 contexts on sites along the middle Red River (see Perino 1983, 1994). Simms Engraved, var. Darco vessels have been recovered from a number of late $17^{\text {th }}$ to mid- $18^{\text {th }}$ century Caddo burial features in East Texas, but the Womack Engraved, var. Culpepper vessels from the site are not represented in the early to mid- $18^{\text {th }}$ century varieties from either the Womack site (Harris et al. 1965) or the Gilbert site (Story et al. 1967:Figure 49). Womack Engraved, var. Culpepper likely represents an early, late $17^{\text {th }}$ century, variety of Womack Engraved, stylistically intermediate between certain Taylor Engraved vessels and var. $B$ and var. $D$ of Womack Engraved (Story et al. 1967:Figure 49b, d).

The vessels from the burial features at the Culpepper site are dominated by fine wares: engraved bottles, bowls, carinated bowls, and jars, a number of which are also red-slipped on interior and exterior surfaces. Fine ware vessels comprise almost 83 percent of the vessel assemblage at the site, followed by utility ware vessels (14 percent), and one plain ware vessel (Table 1).

Table 1. Wares represented in the vessels from the Culpepper site.

\begin{tabular}{lll}
\hline Ware & No. & Percentage \\
\hline Plain & 1 & 2.9 \\
Utility & 5 & 14.3 \\
Fine & 29 & 82.9 \\
\hline Totals & 35 & 100.0 \\
\hline
\end{tabular}

The vessels are mainly grog-tempered (88.6 percent of the vessel assemblage) (Table 2). Four fine ware vessels, however, are shell-tempered, and the decorative elements on these vessels (see below) indicate that they were made by McCurtain phase Caddo peoples living along the middle reaches of the Red River, perhaps in the Mound Prairie area in Red River County, Texas.

Table 2. Tempers represented in the vessels from the Culpepper site.

\begin{tabular}{llll}
\hline Ware & Grog & Shell & Percentage Grog \\
\hline Plain & 1 & - & 100.0 \\
Utility & 5 & - & 100.0 \\
Fine & 25 & 4 & 86.2 \\
\hline Totals & 31 & 4 & 88.6 \\
\hline
\end{tabular}


The one plain ware vessel is a jar, as are the five utility ware vessels (Table 3). The fine wares include bottles (17 percent, including a Hudson Engraved bottle with a spool neck), one shell-tempered bowl (3.4 percent), jars (10.3 percent), including two Taylor Engraved jars, and primarily carinated bowls (69.0 percent of the fine ware vessels). Nineteen of the 20 carinated bowls have inverted rims, a post-ca. A.D. 1670 vessel trait in protohistoric and early historic Caddo sites in parts of East Texas (Perttula 2007:136-144). Eighty percent of the bottles have a spool neck, another attribute of late $17^{\text {th }}$ to early $18^{\text {th }}$ century Caddo vessel assemblages in parts of East Texas.

Table 3. Vessel forms represented in the vessels from the Culpepper site.

\begin{tabular}{lllll}
\hline Form & Plain & Utility & Fine & N \\
\hline Bottle-spool neck & - & - & 4 & 4 \\
Bottle & - & - & 1 & 1 \\
Bowl & - & - & 1 & 1 \\
Carinated bowl & - & - & 20 & 20 \\
Jar & 1 & 5 & 3 & 9 \\
\hline Totals & 1 & 5 & 29 & 35 \\
\hline
\end{tabular}

Defined ceramic types in the vessel assemblage from the Culpepper site include Harleton Appliqued and La Rue Neck Banded jars, all grog-tempered, and several fine ware types (Table 4). The most common fine ware is grog-tempered Ripley Engraved ( $\mathrm{n}=11,38$ percent of the fine ware vessels), including vessels of var. Carpenter, var. Galt, var. Gandy, and var. Pilgrims; var. Gandy vessels with engraved scroll motifs are particularly well represented. Other grog-tempered fine ware types are Keno Trailed, Simms Engraved, Simms Engraved, var. Darco, Taylor Engraved, Wilder Engraved, var. unspecified, and Womack Engraved, var. Culpepper.

Table 4. Defined ceramic types in the vessels from the Culpepper site.

\begin{tabular}{llll}
\hline Type & No. & Grog & Shell \\
\hline Harleton Appliqued & 1 & 1 & - \\
Hudson Engraved & 1 & - & 1 \\
Keno Trailed & 2 & 2 & - \\
La Rue Neck Banded & 4 & 4 & - \\
Ripley Engraved, var. Carpenter & 1 & 1 & - \\
Ripley Engraved, var. Galt & 2 & 2 & - \\
Ripley Engraved, var. Gandy & 7 & 7 & - \\
Ripley Engraved, var. Pilgrims & 1 & 1 & - \\
Simms Engraved & 1 & 1 & - \\
Simms Engraved, var. Darco & 1 & 2 & 2 \\
Taylor Engraved & 4 & 1 & - \\
Wilder Engraved, var. unspecified & 1 & 3 & 1 \\
Womack Engraved, var. Culpepper & 3 & & - \\
Unidentified Engraved & 5 & 4 & 4 \\
Unidentified Plain & 1 & 1 & - \\
\hline Totals & 35 & 31 & \\
\hline
\end{tabular}


The one Hudson Engraved bottle is shell-tempered, as are two Taylor Engraved jars or deep bowls (see Table 4). The other shell-tempered fine ware vessel is a bowl with distinctive rectilinear hatched and crosshatched engraved elements (see Figure 31).

More than 31 percent of the fine ware vessels have had either a red $(n=6)$ or white $(n=3)$ clay pigment rubbed in the engraved designs. All three of the Womack Engraved, var. Culpepper carinated bowls have a red clay pigment, as does one Ripley Engraved, var. Gandy carinated bowl, a Taylor Engraved spool-necked bottle, and a Simms Engraved, var. Darco carinated bowl. The fine ware vessels with a white clay pigment include a Keno Trailed bottle, a Ripley Engraved, var. Carpenter carinated bowl, and a Ripley Engraved, var. Gandy carinated bowl.

Nine different fine ware vessels ( 31 percent) have had a red slip applied to the interior and exterior vessel surfaces. These include the two shell-tempered Taylor Engraved jars or deep bowls, four Ripley Engraved carinated bowls (three of var. Gandy and one var. Carpenter), and three vessels (two carinated bowls and a jar) with unidentified engraved elements; the engraved jar has decorative elements very similar to several vessels recovered in ca. A.D. 1650-1700 contexts at McCurtain phase Caddo sites on the Red River (see Perino 1983, 1994).

Including the one Womack Engraved, var. Culpepper carinated bowl from the Tuinier Farm site (41HP237) (Figure 34), the range of vessels of defined types is very similar to the vessel assemblage from the Culpepper site (Table 5). Ripley Engraved vessels comprise 27.8 percent of these vessels. Simms Engraved and Taylor Engraved vessels are also common at the other Stouts Creek sites. La Rue Neck Banded is the most common utility ware in the burial vessels at these sites. Two of the vessels (11.1 percent) are shell-tempered McCurtain phase vessels: a Hudson Engraved bottle and a Nash Neck Banded jar (Table 5); 11.4 percent of the vessels from the Culpepper site are shell-tempered.

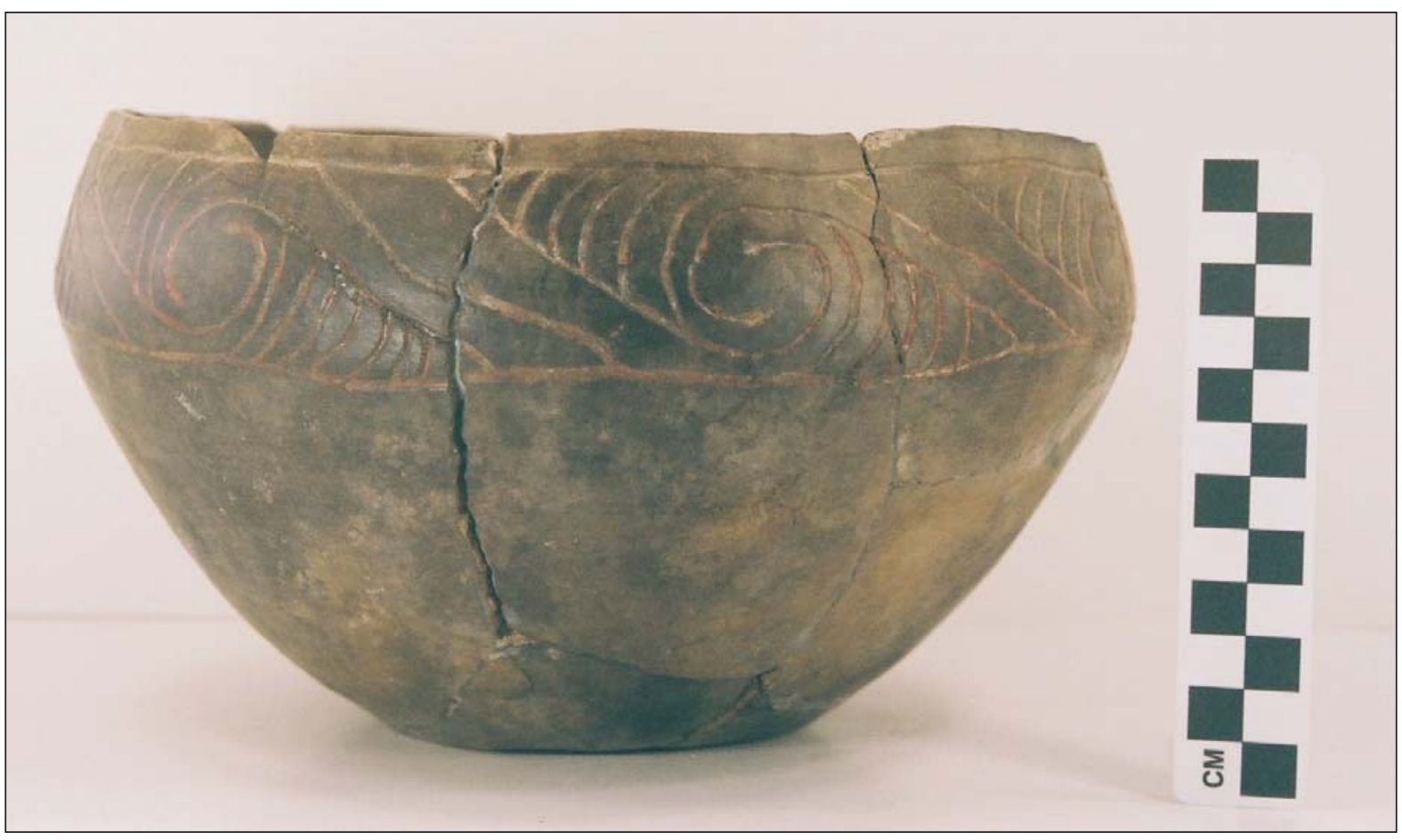

Figure 34. Womack Engraved, var. Culpepper carinated bowl from the Tuinier Farm site (41HP237). 
Table 5. Vessels recovered from other Stouts Creek archaeological sites (from Perttula 2009).

\begin{tabular}{lll}
\hline Type & No. & Percentage \\
\hline Hudson Engraved & $1^{*}$ & 5.6 \\
La Rue Neck Banded & 3 & 16.7 \\
McKinney Appliqued & 1 & 5.6 \\
Nash Neck Banded & $1^{*}$ & 5.6 \\
Ripley Engraved, var. Galt & 1 & 5.6 \\
Ripley Engraved, var. Gandy & 2 & 11.1 \\
Ripley Engraved, var. Pilgrims & 2 & 11.1 \\
Simms Engraved & 3 & 16.7 \\
Taylor Engraved & 3 & 16.7 \\
Womack Engraved, var. Culpepper & 1 & 5.6 \\
\hline Totals & 18 & 100.0 \\
\hline
\end{tabular}

*shell-tempered

The late Titus phase ceramic assemblages at the known sites on Stouts Creek, including the Culpepper site discussed in this article, belong with the western ceramic tradition of the Titus phase Caddo (Perttula 2005:404-405): this tradition is marked by higher frequencies of plain wares than eastern ceramic tradition Titus phase sites, as well as punctated utility wares (although not in the Stouts Creek vessel assemblages), La Rue Neck Banded utility wares, abundant use of red-slipping on fine ware vessels, as well as several different varieties of Ripley Engraved and other fine wares, including Simms Engraved, Taylor Engraved, and Womack Engraved. Western tradition Titus phase sites occur in the middle and upper parts of the Big Cypress Creek basin, as well as in the upper Sabine and White Oak Creek basins (Figure 35). Western tradition sites tend also to have shell-tempered trade wares from McCurtain phase Caddo groups living to the north along the mid-reaches of the Red River in the Mound Prairie area (Figure 36).

The ceramic decorative category data discussed and tabulated by Perttula (2009:Table 25) points to close stylistic and cultural affiliations between the Stouts Creek Titus phase sites and contemporaneous Titus phase sites in the Dry Creek locality in the Lake Fork Creek basin not far to the south (see Figure 35), as well as to other Titus phase communities within a $20-30 \mathrm{~km}$ radius to the north, south, and east-southeast. Even within these areas, however, there existed considerable local and intra-areal diversity in the character of the decorated utility ware and fine ware vessels made and used by different but socially interactive Titus phase communities. Sites in these areas share the considerable use of neck banded and appliqued utility wares, a minimal use of brushed utility wares, and the relative importance of red-slipped vessels (either plain red-slipped bowls and carinated bowls or engraved red-slipped carinated bowls). Downstream on White Oak Creek, the ceramic assemblage from the James Owens site (41TT769, Walters et al. 2003) also has considerable amounts of neck banded and appliqued utility ware sherds and red-slipped vessel sherds, but with moderate proportion of brushed jar sherds (see Perttula 2009:Table 25). Appliqued utility wares are important in Caney Creek locality Titus phase sites, but red-slipped sherds, neck banded sherds, and brushed pottery sherds are relatively negligible. Red-slipped vessel sherds are also an important part of Titus phase ceramic assemblages at the Pilgrim's Pride (41CP304) and Underwood (41CP230) sites in the western part of the Big Cypress Creek drainage.

In summary, the Culpepper site and other Titus phase sites along Stouts Creek (Tuinier Farm, Anglin, and R. A. Watkins sites) are part of a very distinctive western Titus phase community that lived in the Post Oak Savannah in the Stouts Creek valley in the late $16^{\text {th }}$ century and much of the $17^{\text {th }}$ century A.D. The stylistic character of the ceramic vessels from the Culpepper site suggest the cemetery there was used by Caddo peoples in the $17^{\text {th }}$ century, perhaps as late as ca. A.D. 1680, prior to any sustained contact between Caddo groups and European explorers and traders. 


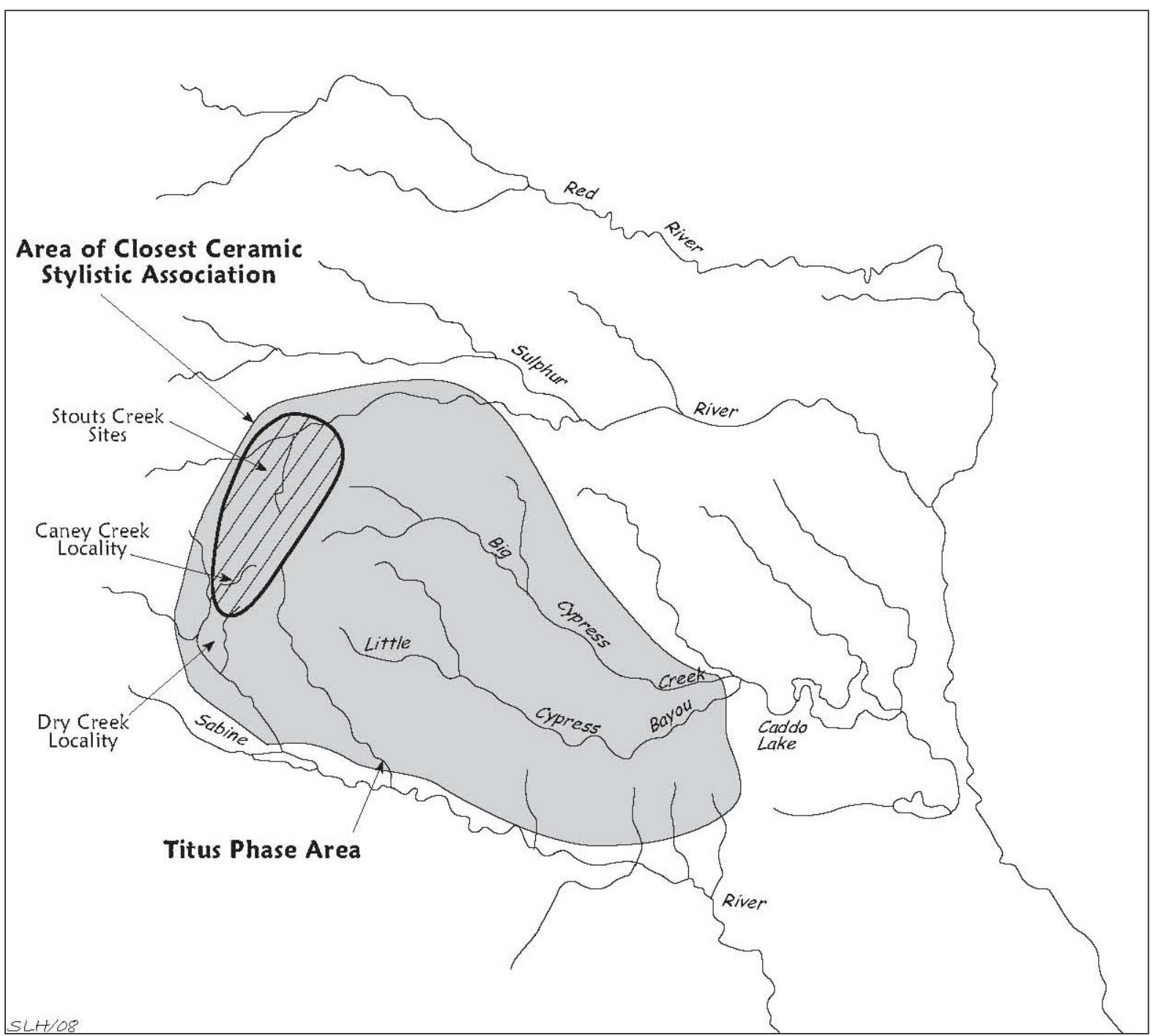

Figure 35. Map of the Titus phase area, depicting the area with sites having the closest stylistic associations with the ceramic assemblages in the Stouts Creek locality.

\section{Acknowledgments}

I thank the Texas Archeological Research Laboratory at The University of Texas at Austin, particularly Marybeth Tomka, for access to the vessel collections from the Culpepper site for documentation purposes. Sandy Hannum prepared Figures 1-3 and 35-36 in the article, and Lance Trask prepared the remainder of the figures.

\section{References Cited}

Diggs, G. M. , Jr., B. L. Lipscomb, M. D. Reed, and R. J. O’Kennon

2006 Illustrated Flora of East Texas, Volume One: Introduction, Pteridophytes, Gymnosperms, and Monocotyledons. Botanical Research Institute of Texas, Fort Worth.

Fields, R. C., V. L. Hatfield, D. Burden, E. F. Gadus, M. C. Wilder, and K. W. Kibler

2014 Testing and Data Recovery Excavations at 11 Native American Archeological Sites along the U.S. Highway 271 Mount Pleasant Relief Route, Titus County, Texas. 2 Vols. Reports of Investigations No. 168. Prewitt and Associates, Inc., Austin. 


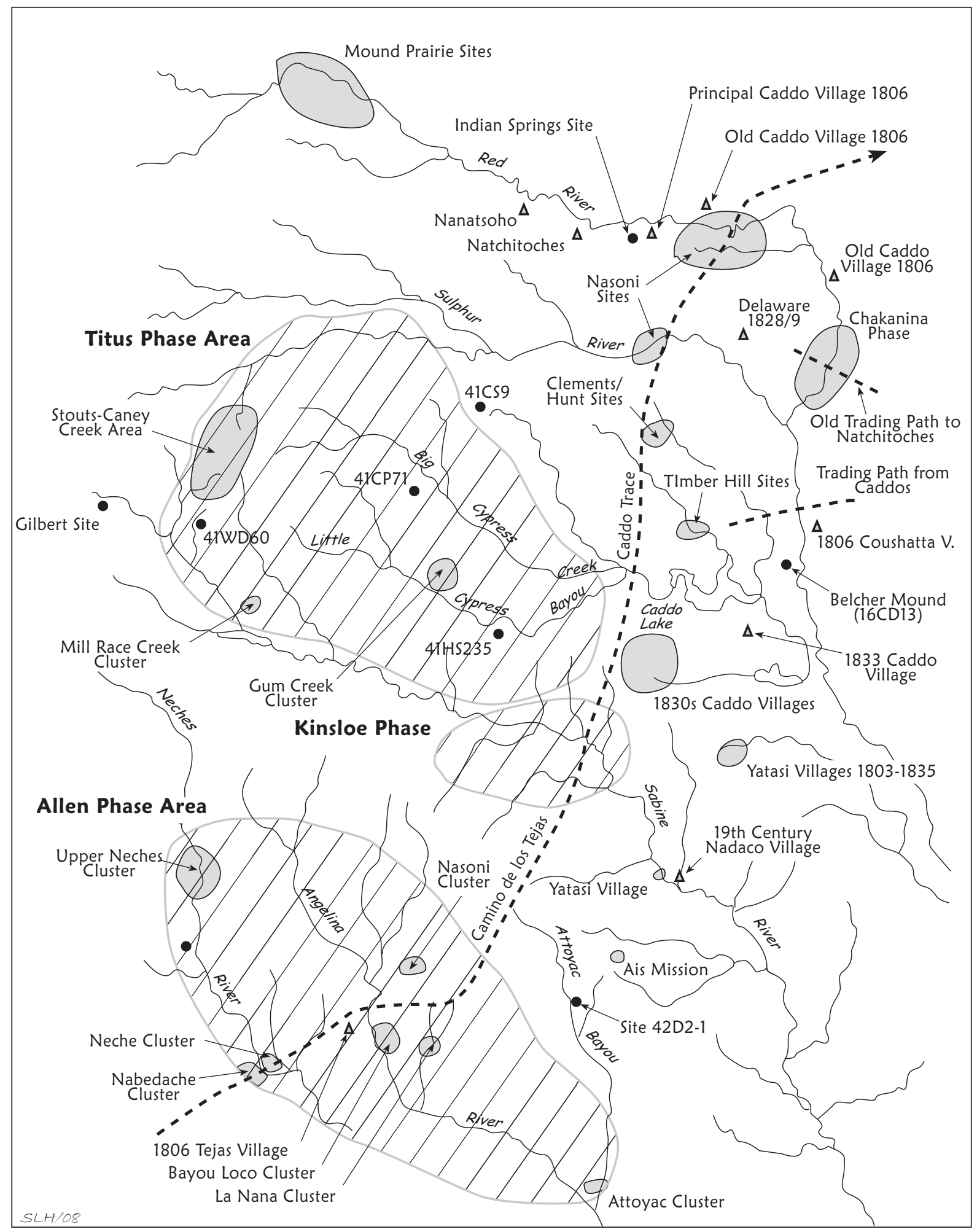

Figure 36. The Stouts/Caney Creek areas in East Texas, showing relevant protohistoric and Historic Caddo sites and archaeological phases, as well as the general location of some villages and trails mentioned in historic documents and maps. 
Harris, R. K., I. M. Harris, J. C. Blaine, and J. Blaine

1965 A Preliminary Archeological and Documentary Study of the Womack Site, Lamar County, Texas. Bulletin of the Texas Archeological Society 36:287-365.

Jordan, T. G.

1981 Trails to Texas: Southern Roots of Western Cattle Ranching. University of Nebraska Press, Lincoln.

Perino, G.

1983 Archaeological Research at the Bob Williams Site (41RR16), Red River County, Texas. Museum of the Red River, Idabel.

1994 Archaeological Research at the Rowland Clark Site (41RR77), Red River County, Texas. Journal of Northeast Texas Archaeology 4:3-42.

Perttula, T. K.

2007 Inverted Rim Engraved Vessels in Protohistoric and early Historic Caddo Sites in Parts of Northeast Texas. Journal of Northeast Texas Archaeology 26:136-144.

2009 The Archaeology of the 16th and 17th Century Caddo in the Post Oak Savannah of Northeast Texas: The Tuinier Farm (41HP237), R. A. Watkins (41HP238), and Anglin (41HP240) Sites in the Stouts Creek Basin, Hopkins County, Texas. Journal of Northeast Texas Archaeology 30:1-132.

Perttula, T. K. (editor)

2005 Archeological Investigations at the Pilgrim's Pride Site (41CP304), a Titus Phase Community in the Big Cypress Creek Basin, Camp County, Texas. 2 Vols. Report of Investigations. Archeological \& Environmental Consultants, LLC, Austin.

Scurlock, J. D.

1962 The Culpepper Site, a Late Fulton Aspect Site in Northeast Texas. Bulletin of the Texas Archeological Society 32:285-316.

Story, D. A., B. Barber, E. Cobb, H. Cobb, R. Coleman, K. Gilmore, R. K. Harris, and N. Hoffrichter

1967 Pottery Vessels. In "The Gilbert Site: A Norteno Focus Site in Northeast Texas," edited by E. B. Jelks. Bulletin of the Texas Archeological Society 37:112-187.

Suhm, D. A. and E. B. Jelks (editors)

1962 Handbook of Texas Archeology: Type Descriptions. Special Publication No. 1, Texas Archeological Society, and Bulletin No. 4, Texas Memorial Museum, Austin. Reprinted in 2009, Gustav's Library, Davenport, Iowa.

Walters, M., B. Boyd, B. Nelson, L. Schniebs, and T. K. Perttula

2003 The James Owens Site (41TT769) in the Sulphur River Basin of Northeast Texas. Caddoan Archeology Journal 13(1):16-34. 